\title{
Summary of Hanford Site Groundwater Monitoring for Fiscal Year 2002
}

\section{Editors}

\author{
M. J. Hartman \\ L. F. Morasch \\ W. D. Webber
}

March 2003

Prepared for the U.S. Department of Energy

by Pacific Northwest National Laboratory under Contract DE-AC06-76RL01830, with contributions from Bechtel Hanford, Inc.; Boise State University; CH2M HILL Hanford, Inc.; CH2M HILL Hanford Group, Inc.; Fluor Hanford, Inc.; Idaho National Engineering and Environmental Laboratory; and S. M. Stoller Corporation

Pacific Northwest National Laboratory Richland, Washington 99352 


\title{
DISCLAIMER
}

This report was prepared as an account of work sponsored by an agency of the United States Government. Reference herein to any specific commercial product, process, or service by trade name, trademark, manufacturer, or otherwise does not necessarily constitute or imply its endorsement, recommendation, or favoring by the United States Government or any agency thereof, or Battelle Memorial Institute.

\author{
PACIFIC NORTHWEST NATIONAL LABORATORY \\ operated by \\ BATTELLE \\ for the \\ UNITED STATES DEPARTMENT OF ENERGY \\ under Contract DE-AC06-76RL01830
}

Printed in the United States of America

Available to DOE and DOE contractors from the

Office of Scientific and Technical Information, P.O. Box 62, Oak Ridge, TN 37831; prices available from (615) 576-8401.

Available to the public from the National Technical Information Service, U.S. Department of Commerce, 5285 Port Royal Rd., Springfield, VA 22161

Cover Photo: The present and past natural history of the Hanford Site come together along the last free-flowing stretch of the Columbia River. The active sands dunes of the Hanford Reach National Monument march eastward across the desert to the Columbia River with the ancestral Columbia River deposits of White Bluffs forming a backdrop. The mission of the U.S. Department of Energy's Groundwater Protection Program is to protect this environment and human health from contaminated groundwater resulting from past, present, and future operations at the Hanford Site. Therefore, groundwater monitoring is an integral part of current remediation at Hanford and will remain a component of longterm stewardship after remediation is complete.

The cover photo is from LMSI (92100762-24cn), Richland, Washington. The cover design is by S. B. Neely and the text layout is by K. R. Neiderhiser, both of Pacific Northwest National Laboratory, Richland, Washington. 


\section{Contents}

Introduction

Groundwater Monitoring Highlights for Fiscal Year 2002

Vadose Zone Highlights for Fiscal Year 2002

Emerging Issues

Groundwater Flow and Movement

Overview of Contaminants

Groundwater Remediation and Monitoring of CERCLA Operable Units

100 Areas Groundwater Contamination

200 Areas Groundwater Contamination

400 Area Groundwater Contamination

300 Area Groundwater Contamination

Richland North Area Groundwater Contamination

Upper Basalt-Confined Aquifer

Groundwater Monitoring of RCRA Treatment, Storage, and Disposal Units

Well Installation

Modeling . 26

Vadose Zone

Glossary 
This booklet summarizes a more detailed report, Hanford Site Groundwater Monitoring for Fiscal Year 2002. That report is prepared annually to present the results of groundwater and vadose zone monitoring and remediation on the U.S. Department of Energy's Hanford Site in Washington State. The U.S. Department of Energy monitors groundwater at the Hanford Site to fulfill a variety of state and federal regulations. The department manages these activities through the Hanford Groundwater Monitoring Project, which is conducted by Pacific Northwest National Laboratory. The results primarily rely on data from samples collected between October 1, 2001, and September 30, 2002.

This summary booklet is designed to briefly (1) describe the highlights for fiscal year 2002; (2) identify emerging issues in groundwater monitoring; (3) discuss groundwater flow and movement; and (4) provide an overview of current contamination in the Hanford Site groundwater and vadose zone.

For more information about the groundwater project, see http://groundwater.pnl.gov. To obtain copies of this summary booklet, the detailed annual report, or a copy of the reports on CD, contact M. J. Hartman at Pacific Northwest National Laboratory, P.O. Box 999, MS K6-96, Richland, Washington 99352 or by electronic mail to mary.hartman@pnl.gov. 


\section{Introduction}

The Hanford Site, a facility in the U.S. Department of Energy (DOE) nuclear weapons complex, encompasses $\sim 1,517$ square kilometers northwest of the city of Richland along the Columbia River in southeast Washington State. The site was acquired by the federal government in 1943, and until the 1980s was dedicated primarily to the production of plutonium for national defense and the management of resulting waste.

In 1995, all unrestricted discharge of radioactive liquid waste to the ground was discontinued. Today, DOE's mission on the Hanford Site is to restore the Columbia River corridor, transition the central portion of the site toward its longterm waste management role, and prepare for the future.

DOE has monitored groundwater on the Hanford Site since the 1940s to help determine what chemical and radiological contaminants have made their way into the vadose zone and groundwater. As regulatory requirements for monitoring increased in the 1980s, there began to be some overlap between various programs. DOE established the Hanford Groundwater Monitoring Project (groundwater project) in 1996 to ensure protection of the public and the environment while improving the efficiency of monitoring activities. The groundwater project is

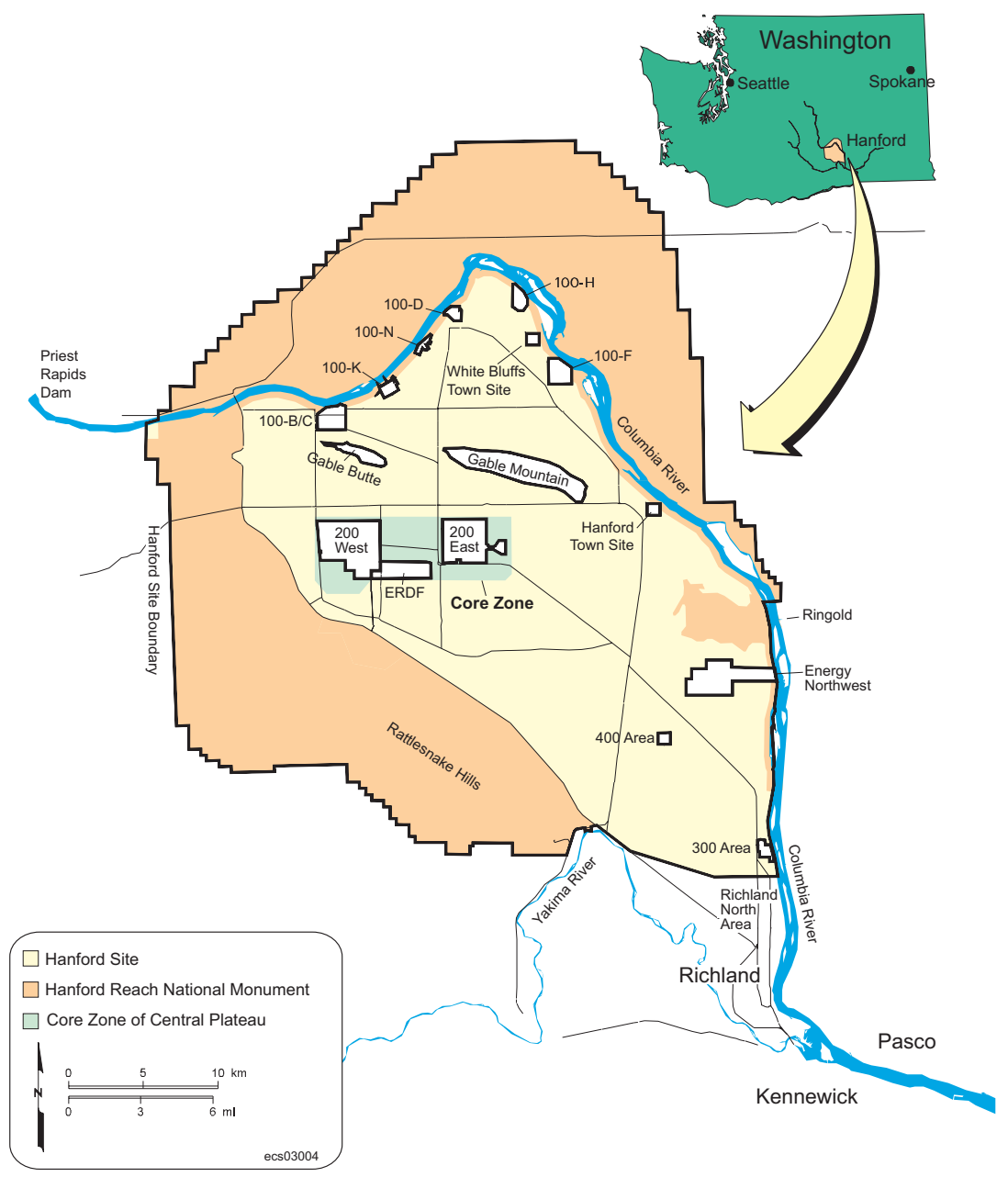

The Hanford Site occupies approximately 1,517 square kilometers of arid land in southeastern Washington.
Groundwater is the water that fills the pores or cracks between grains in a layer of sediment or rock. An aquifer is a geologic layer that allows water to pass through easily, with all its pores saturated with water. The top of the saturated zone is called the water table. The vadose zone is the soil or rock between the ground surface and the water table. It usually contains some water, but also contains air.
Groundwater monitoring helps determine what contamination exists beneath the Hanford Site. This information will help regulators and DOE make cleanup decisions based on scientific information and technical capabilities. 
This report is written to meet the requirements in the Comprehensive Environmental Response, Compensation, and Liability Act (CERCLA), Resource Conservation and Recovery Act (RCRA), Atomic Energy Act of 1954, and Washington Administrative Code.
The Hanford Groundwater Monitoring Project sampled 650 wells during fiscal year 2002. lodine-129, nitrate, and tritium are the most widespread contaminants. designed to support all groundwater monitoring needs at the site, eliminate regulatory program redundancy, and establish a cost-effective hierarchy for groundwater monitoring activities. Specific objectives include

- maintain and verify compliance with all applicable groundwater regulations

- characterize and define physical and chemical trends in groundwater

- establish baselines of groundwater quality

- provide continuing, independent assessment of groundwater remediation activities

- identify and quantify new or existing groundwater problems

Contamination may reach the Columbia River by moving down through the vadose zone, into the groundwater, and then into the river. The analysis of groundwater samples helps determine the potential effects that contaminants in Hanford soil and groundwater could have on human health and the environment. DOE works with the regulators, such as the U.S. Environmental Protection Agency (EPA) and the Washington State Department of Ecology, to make cleanup decisions based on sound technical information and the technical capabilities available.

\section{Groundwater Highlights for Fiscal Year 2002}

DOE's major accomplishments related to groundwater monitoring in fiscal year 2002 included the following:

- Workers sampled $\sim 650$ monitoring wells to determine the distribution and movement of contaminants. Many of these wells were sampled multiple times during the year. Data from these samples were used to identify and characterize existing, potential, and emerging groundwater contamination problems.

- During the past year, 1,756 samples of Hanford groundwater were analyzed for chromium, 1,086 for nitrate, and 913 for tritium. Other frequently-analyzed constituents include carbon tetrachloride, technetium-99, and uranium, which were analyzed in $\sim 600$ samples.

- Interim remedial measures continued to limit the spread of groundwater contamination in the 100 and 200 Areas. Since their inception, remedial measures

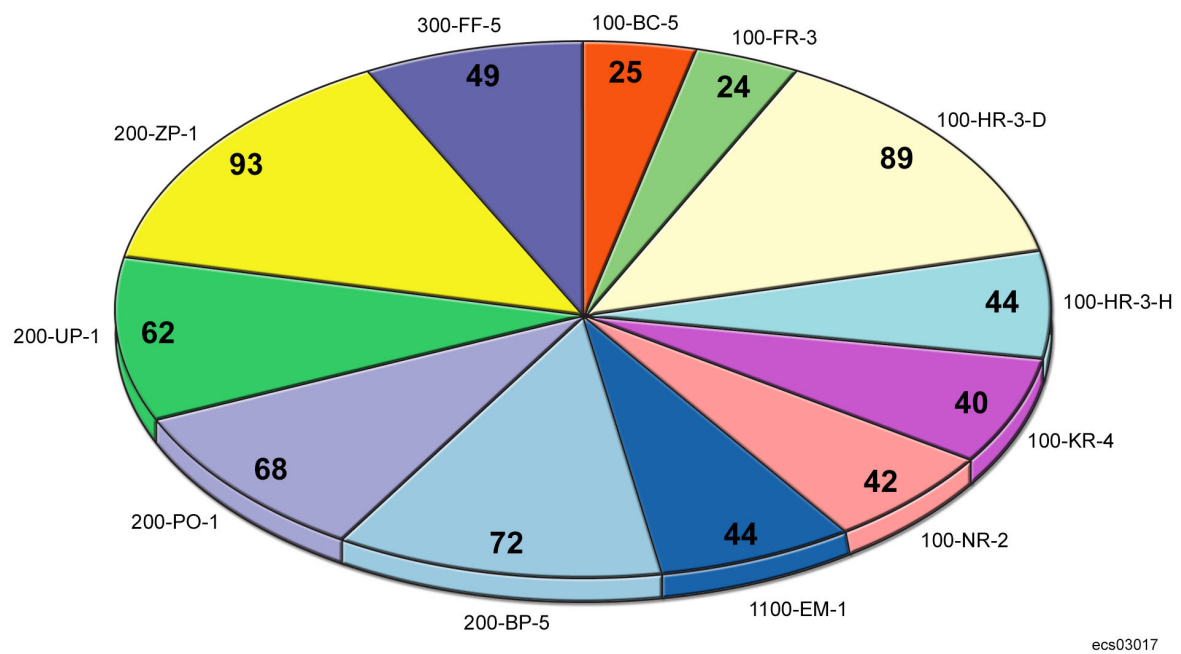

Hanford Site groundwater monitoring is organized by areas of interest, which are informally named after the groundwater operable units. This chart shows the number of wells sampled in each region in fiscal year 2002. 
have treated over 6 billion liters of groundwater to remove carbon tetrachloride, chromium, nitrate, technetium-99, and uranium.

- Average trichloroethene concentrations in compliance wells in the 1100-EM-1 Operable Unit (Richland North Area) remained below the maximum contaminant level for the second year in a row. This contaminant has been attenuating naturally, more rapidly than expected.

- The groundwater project continued to monitor 24 Resource Conservation and Recovery Act (RCRA) sites, 5 other regulated units, and 11 Comprehensive Environmental Response, Compensation, and Liability Act (CERCLA) groundwater operable units.

- RCRA monitoring provided no evidence of new contamination from sites in detection programs. Seven sites continued to be monitored under assessment programs, and two under final-status corrective action.

- The groundwater project evaluated the adequacy of RCRA monitoring networks. At single-shell tank Waste Management Areas A-AX and C, the direction of groundwater flow has been re-interpreted and the monitoring networks are being modified. Because the water table is dropping in the 200 Areas, many monitoring wells have gone dry in recent years. Networks contain fewer than the minimum required number of wells at 216-S-10 pond, 216-U-12 crib, the Liquid Effluent Retention Facility, and Low-Level Waste Management Areas 3 and 4.

- Monitoring provided no evidence of new leaks from fuel storage basins in the 100-K Area.

- Monitoring results at the following regulated units remained within permit limits: 400 Area Process Ponds, State-Approved Land Disposal Site, and Treated Effluent Disposal Facility. Concentrations of some constituents of concern at the Environmental Restoration Disposal Facility were elevated but reflect

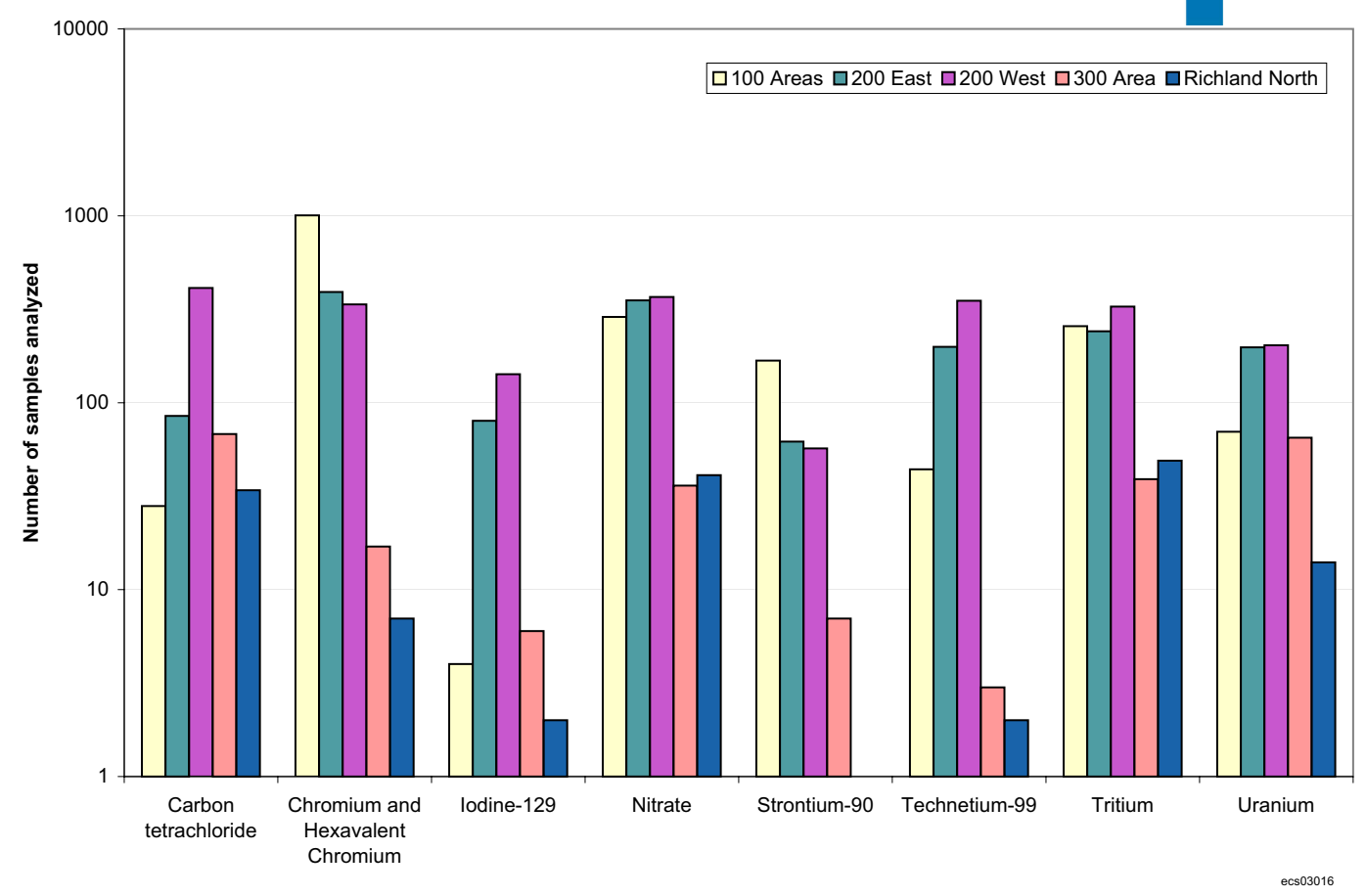

The groundwater project requests specific laboratory analyses based on the well's location, historical contaminant trends, and regulatory requirements. This graph shows the number of analyses for each geographic region during fiscal year 2002. 
A study of the correlation between strontium-90 concentrations and gamma log response was undertaken to help scientists determine a way to measure strontium-90 concentrations in the vadose zone. The results may lead to a method for quantitative measurement of strontium-90 in the subsurface. migration of contaminant plumes from sources in the 200 West Area. At the Solid Waste Landfill, specific conductance, $\mathrm{pH}$, chloride, sulfate, and coliform bacteria exceeded their background threshold levels in one or more samples.

- Monitoring indicated that the tritium plume that originated in the 200 East Area did not move closer to the city of Richland or its water supply wells.

- During calendar year 2002, drillers completed 2 new RCRA monitoring wells, 3 wells to monitor a proposed low-activity waste site in the 200 East Area, 21 wells for groundwater remediation and monitoring in the 100-D Area, and 2 wells for groundwater remediation and monitoring in the 200 West Area.

- In fiscal year 2002, development of the site-wide groundwater model focused on improvements to the base-case model and development of additional alternative conceptual models.

- The System Assessment Capability is a set of computer modules simulating movement of contaminants from waste sites through the vadose zone and groundwater. In fiscal year 2002, scientists completed an initial assessment of 10 contaminants released from 890 waste sites, simulating movement of the contaminants from 1944 through 3050.

\section{Vadose Zone Highlights for Fiscal Year 2002}

The vadose zone is the area between the ground surface and the water table. Many activities focused on the vadose zone to further understand the physical and chemical properties of this area in an attempt to limit the migration of contamination. The work is designed to result in new, innovative methods for cleanup and monitoring at the Hanford Site. DOE's accomplishments in vadose zone work included the following:

- Scientist used sediment samples from boreholes at the B-BX-BY Tank Farms to study the distribution and mobility of radionuclides. Under current conditions, strontium-90 and uranium appear to be relatively immobile, but uranium could become mobile under certain chemical and physical conditions.

- Researchers studied soil gas at the 618-10 burial ground in the southeast part of the Hanford Site to determine whether there is a previously undiscovered tritium plume in the vadose zone or in groundwater. Results did not indicate a new plume.

- Geophysicists investigated the possibility of using gamma logging to identify zones of strontium-90 contamination in sediment around boreholes. Results showed a strong correlation between strontium-90 and gamma activity, and may lead to a method for quantitative measurement of strontium-90 in the subsurface.

- DOE expanded their efforts to protect tank farms from the effects of infiltrating water. Workers built berms and installed a culvert to divert ponded precipitation from tank farms in the 200 East Area before it can infiltrate. Workers tested water lines and cut and capped those that are not needed. Similar efforts were conducted for the 200 West Area tank farms in fiscal year 2001.

- Workers drilled and sampled three boreholes in locations of known or suspected contamination in the TX Tank Farm. One of the boreholes was outfitted with vadose zone monitoring equipment as it was backfilled. 


\section{Emerging Issues}

As monitoring, remediation, and related work progress, new issues of potential concern arise. Some of the issues that DOE will address in coming years include the following:

- Integration of Monitoring - Long-term groundwater monitoring under CERCLA, RCRA Past-Practice, or the Atomic Energy Act of 1954 share many of the same objectives, i.e., to track contaminant plumes and trends in groundwater. While sampling and analysis already are coordinated, further integration will create even greater efficiency. DOE and the regulators began planning for this type of integration in the 100-BC-5, 100-FR-3, 200-BP-5, 200-PO-1, 200-UP-1, and 200-ZP-1 Operable Units in fiscal year 2002. DOE will continue to work with regulators to integrate monitoring at other groundwater operable units and to develop a plan for long-term stewardship.

- Alternatives to Pump-and-Treat Systems - The objective of interim-action pump-and-treat systems is to limit the spread of existing contamination. In some cases, it is not an effective way to clean up the aquifer. For example, in the 100-N Area, the pump-and-treat system is removing far less strontium-90 than is removed naturally by radioactive decay. DOE is investigating alternative approaches to cleanup, including natural attenuation at some sites.

- Adequacy of Monitoring Networks - As wells in the 200 Areas go dry, some groundwater monitoring networks are no longer adequate to detect new contaminants or assess existing contamination. Installation of new wells at these sites compete for funding with other well needs, e.g., remedial action wells. In 2002, DOE's Cleanup, Constraints, and Challenges Team (C3T) was formed to assess and define well needs to meet all groundwater objectives in the 200 Areas. These wells will be scheduled for installation over the next 4 years according to their relative priority.

Wells in the 200 Areas that were formerly sampled for the Groundwater Project have gone dry as the water table declined. Most of the wells are in the 200 West Area.

\begin{tabular}{|c|c|c|c|c|}
\hline Fiscal Year & 200 West & 200 East & Other Areas & $\underline{\text { Total }}$ \\
\hline 1998 & 2 & 1 & 2 & 5 \\
\hline 1999 & 9 & 0 & 1 & 10 \\
\hline 2000 & 12 & 2 & 2 & 16 \\
\hline 2001 & 7 & 0 & 1 & 8 \\
\hline 2002 & 10 & 2 & 1 & 13 \\
\hline Total & 40 & 5 & 7 & 52 \\
\hline
\end{tabular}

- Transition of RCRA Interim Status Units to Final Status - As RCRA units are incorporated into revisions of the Hanford Facility RCRA Permit, they are subject to the requirements of final-status monitoring (WAC 173303-645). In many cases, this transition requires application of alternative statistical evaluations and, at locations where the water table is declining beneath the bottom of the aquifer, an entirely new approach to monitoring. Such alternatives must be evaluated carefully by scientists, statisticians, and regulators.
The top of an unconfined aquifer is the water table. At Hanford, the unconfined aquifer is in a sequence of sandy, gravelly sediment, and depth to the water table ranges from less than 1 meter near the river to more than 100 meters in the center of the site. Confined aquifers are capped by less permeable layers that cannot transmit much water. Confined aquifers at Hanford occur beneath clay or basalt layers. 
Water-table elevations are measured across the Hanford Site with an electronic water-level tape once each year. In addition, water levels are measured each time a well is sampled during the year.
A groundwater monitoring network strategically located across the Hanford Site helps determine changes in the direction of groundwater flow as the site returns to pre-Hanford conditions.
- Carbon Tetrachloride Distribution - EPA's five-year review of remedial actions, published in fiscal year 2001, cited the need to define the distribution of carbon tetrachloride with depth in the aquifer. Data from wells completed deep in the unconfined aquifer indicate that in some locations, concentrations are higher at depth than they are at the water table. However, relatively few deep wells are available, hindering interpretation.

- BC Cribs and Trenches - These facilities are located south of the 200 East Area and were used from 1956 to 1958. Recent computer models indicate that the majority of tank waste sent to liquid discharge sites was disposed at the $\mathrm{BC}$ cribs and trenches. The constituents of interest include cobalt-60, cyanide, technetium-99, ferrocyanide, and chromium. Groundwater monitoring of this facility is being increased.

- Chromium in 100-D Area - The concentration of hexavalent chromium within a few wells in the redox treatment zone increased unexpectedly. DOE re-injected treatment solution into some of the wells in fiscal year 2002 and will evaluate the need for further action in other wells.

\section{Groundwater Flow and Movement}

Groundwater in the unconfined aquifer generally flows from west to east across the Hanford Site to discharge areas along the Columbia River. The direction of groundwater flow is inferred from water-table elevations, barriers to flow (e.g., basalt or mud units at the water table), and the distribution of contaminants.

General directions of groundwater flow are illustrated on the following map for March 2002. Beneath the reactor areas, groundwater flows generally toward the Columbia River. Groundwater seeps appear along the riverbank when river levels are low. Farther inland, north of Gable Mountain, flow is toward the northeast and east. Groundwater flows eastward beneath the 200 Areas and then flows to the southeast or northward through the gap between Gable Butte and Gable Mountain. Groundwater converges on the 300 Area from the northwest, west, and southwest and discharges into the Columbia River to the east. Groundwater in the Richland North Area flows generally eastward to the Columbia River.

The natural pattern of groundwater flow was altered during the Hanford Site's operating years by the formation of mounds in the water table. The mounds were created by the discharge of large volumes of wastewater to the ground and were present in each reactor area and beneath the 200 Areas. Since effluent disposal has decreased significantly, these mounds are disappearing. The 1990 water-table map shows groundwater mounds beneath the 200 West and 200 East Areas, which created the potential for radial flow near the mounds and induced northward flow toward the gap between Gable Mountain and Gable Butte. The 200 East Area mound is gone and the 200 West Area mound is much less prominent in the fiscal year 2002 map. Water levels east of the 200 East Area have dropped below the top of a fine-grained confining unit, thus creating a barrier to movement in the surrounding unconfined aquifer. Beneath this confining unit, the uppermost aquifer is a permeable unit in the Ringold Formation. Groundwater flow in this confined aquifer still is influenced by the recharge mound that formerly created an unconfined aquifer above the fine-grained confining unit in the area.

Groundwater in the upper basalt-confined aquifer generally flows from west to east across the Hanford Site, up through the unconfined aquifer, and into the Columbia River. Vertical gradients between the basalt-confined aquifer and the unconfined aquifer are upward on most of the Hanford Site. Therefore, there is little potential for contaminants to migrate from the unconfined aquifer into the 

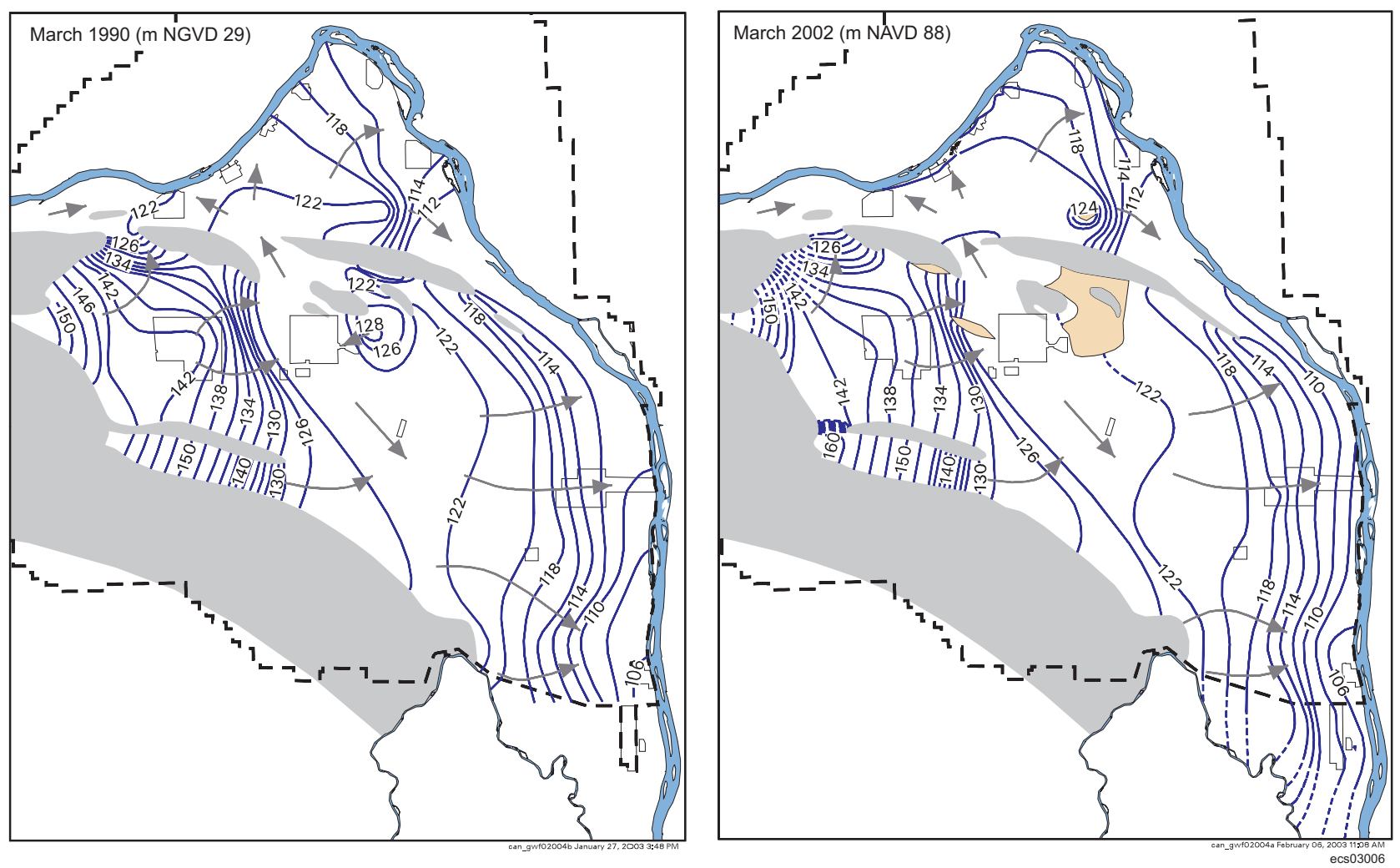

These maps show the water table and inferred flow directions in June 1990 (National Geodetic Vertical Datum of 1929) and March 2002 (North American Vertical Datum of 1988). NGVD29 is approximately 1 meter lower than NAVD88. The water table declined beneath most of the Hanford Site during that period. Shaded areas in both maps show where the unconfined aquifer is absent.

basalt-confined aquifer, where it could move offsite. Downward gradients are measured beneath the west portion of the Hanford Site and north and east of the Columbia River.

\section{Overview of Contaminants}

The goal of DOE's Groundwater Protection Program is to clean up groundwater contaminants, avoid future groundwater contamination, and prevent contaminants from reaching the Columbia River. Some contaminants, including chromium, strontium-90, tritium, and uranium, flow from specific parts of the shoreline called springs or seeps. Springs or seeps are small areas where the groundwater meets the river. Just beyond the seeps in the river, contamination is diluted far below levels of concern for human or ecological health. The Washington State Department of Ecology and the U.S. Geological Survey both gave the Columbia River the highest rating for water quality — Class A, meaning "Excellent" — from the Grand Coulee Dam to the Washington-Oregon border. A Class A rating means that the Columbia River is suitable for all types of water supplies, fish and shellfish habitat, wildlife habitat, human recreational activities, and commerce and navigation. In fact, the Hanford Reach is heavily used for recreational purposes. The Columbia River also is the city of Richland's main source of drinking water; it consistently meets all state and federal drinking water standards.

DOE monitors groundwater quality all across the Hanford Site, even far from the river, to know what contaminants are present and how they are moving. The maps on the following pages show the distribution of nine principal groundwater 


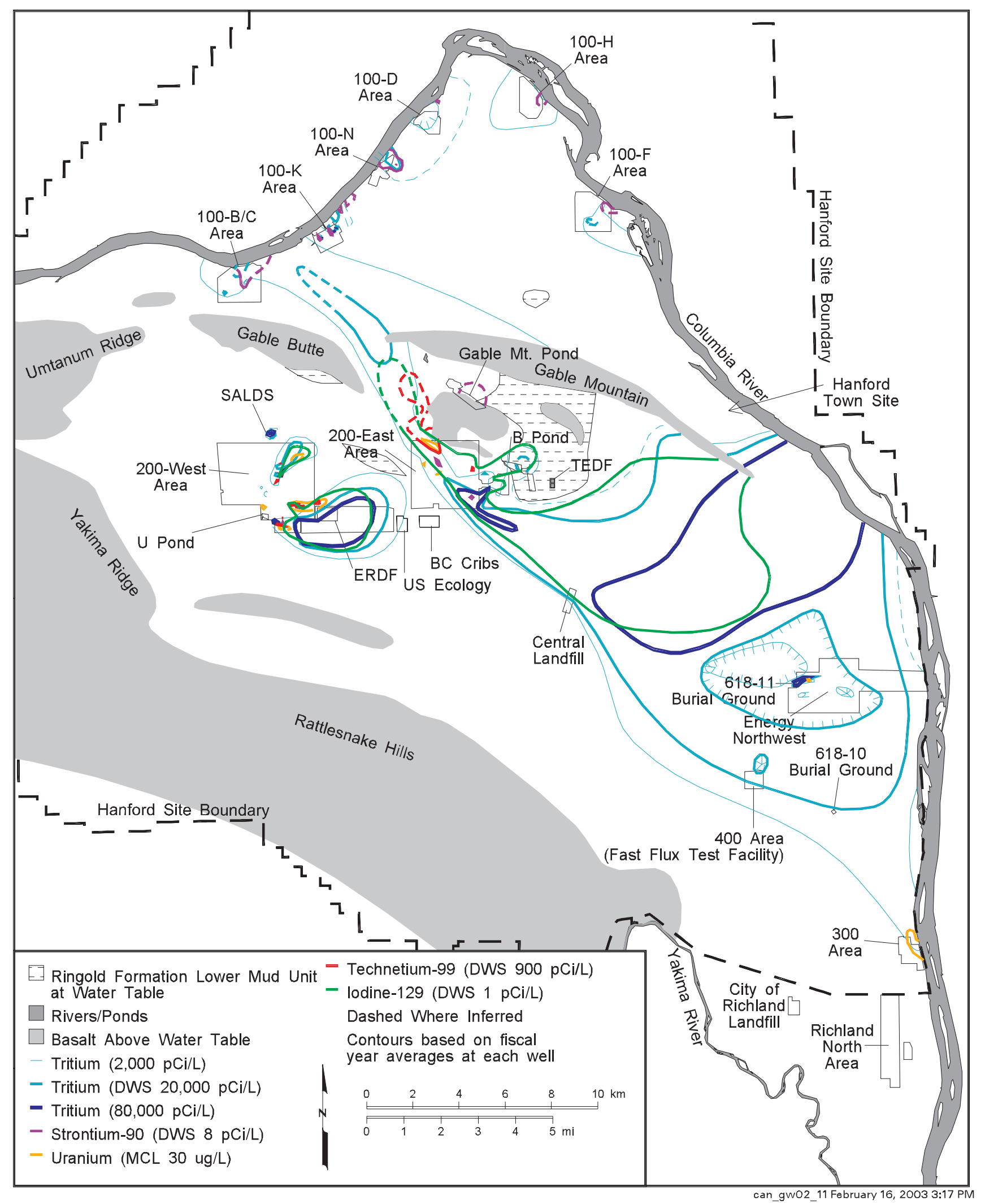

This map shows the distribution of major radionuclides in groundwater at concentrations above maximum contaminant levels or drinking water standards during fiscal year 2002. 


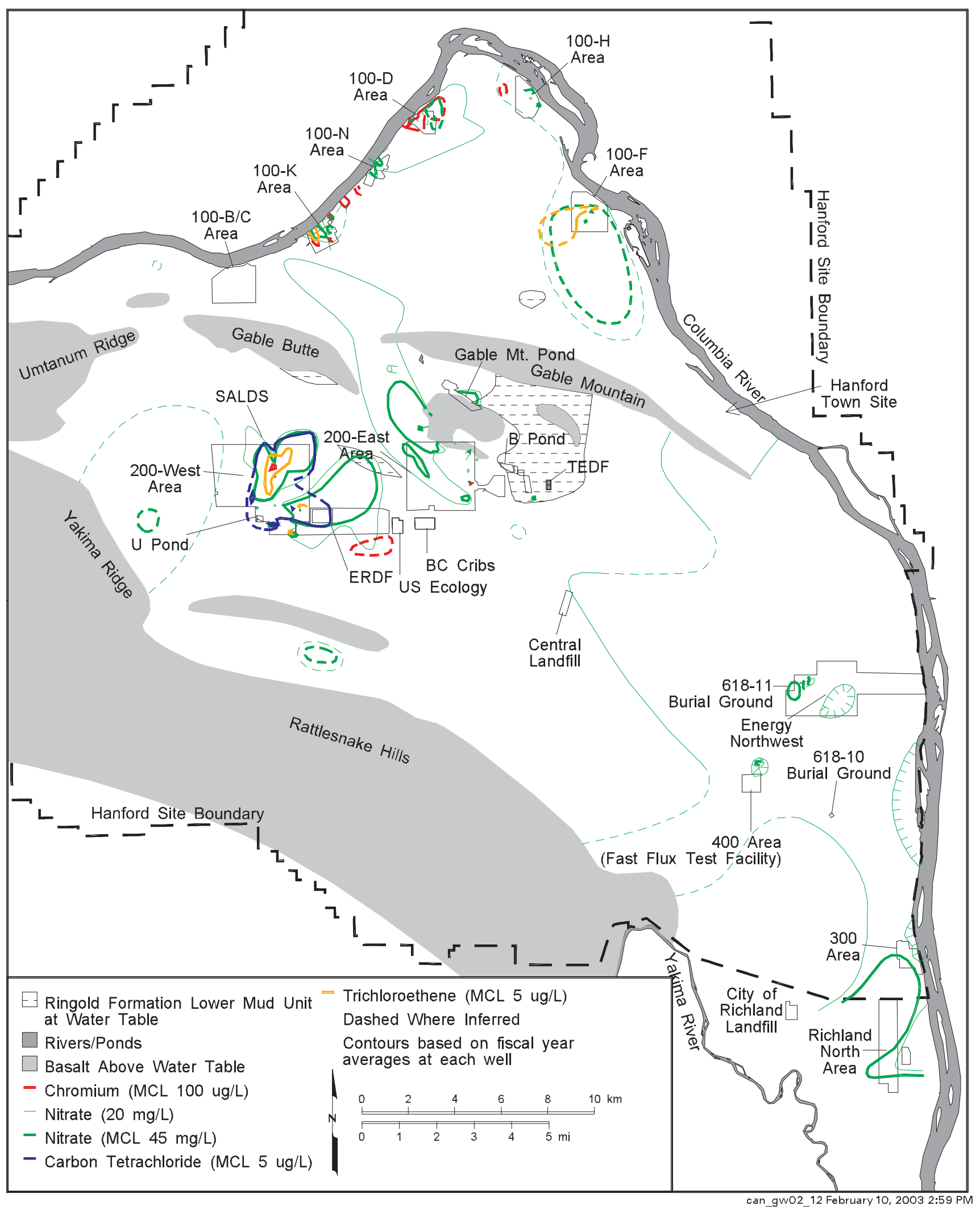

This map shows the distribution of major hazardous chemicals in groundwater at concentrations above maximum contaminant levels during fiscal year 2002. 


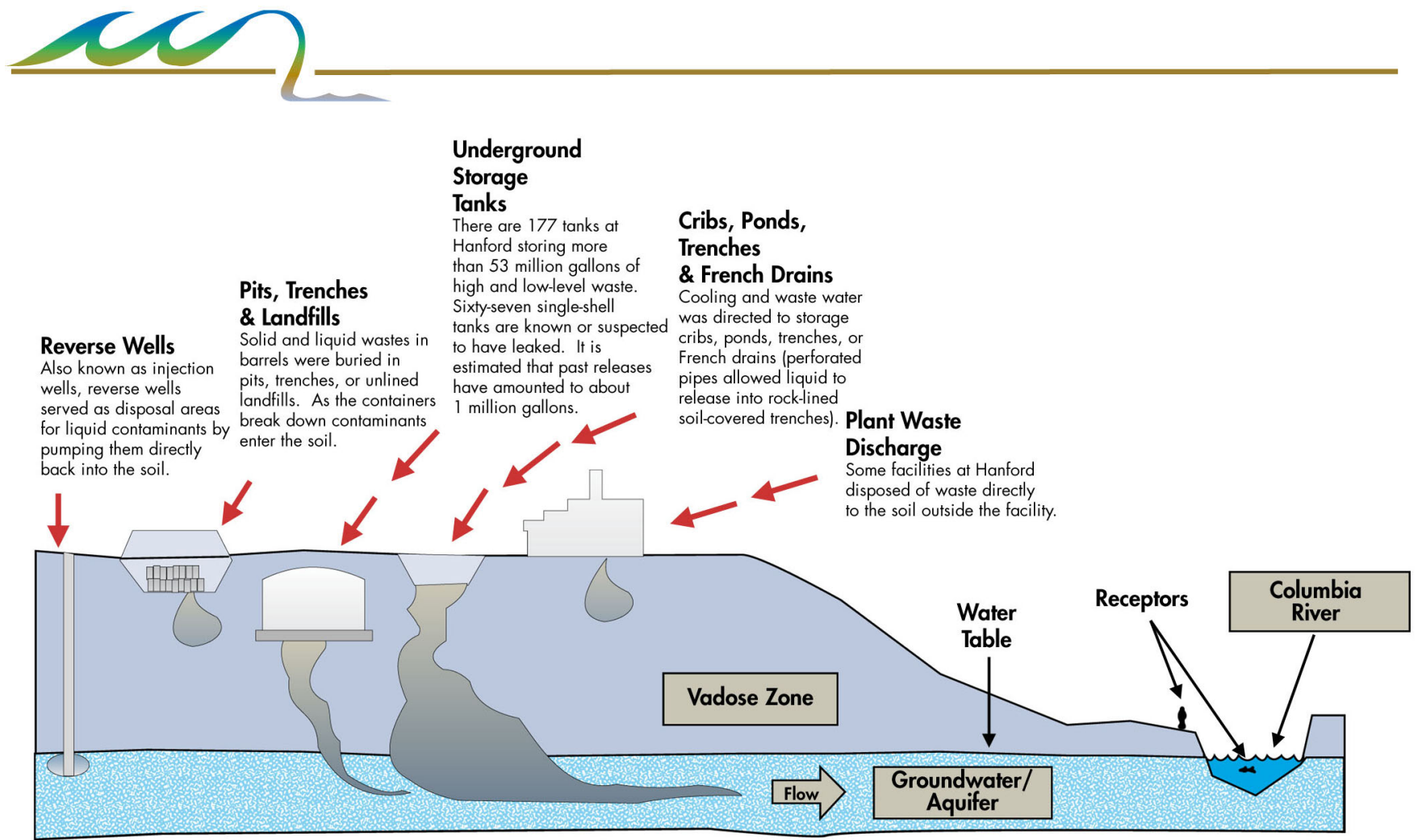

This figure shows the sources of Hanford groundwater contamination. Groundwater is monitored to determine the nature and extent of contamination from Hanford operations.

The chemical and physical characteristics of groundwater vary across areas and time. The interpretation of sampling results must, therefore, be carried out with great care. contaminant plumes. The following paragraphs provide some basic information about contaminants on the Hanford Site, listed in order of largest to smallest plume areas. More specific information is provided in the sections on the geographic regions of the plume sources.

Tritium - Tritium was common in Hanford Site liquid waste discharged to the soil and is the most mobile and most widely distributed radionuclide onsite. It has a relatively short half-life (12.3 years). The drinking water standard, $20,000 \mathrm{pCi} / \mathrm{L}$, is exceeded in parts of the 100,200 , and 600 Areas. The most prominent tritium plume originated from disposal cribs in the 200 East Area near the PlutoniumUranium Extraction (PUREX) Plant and has migrated downgradient to the southeast where it meets the Columbia River.

Iodine-129 - Iodine-129 was present in waste related to fuel processing. The presence of iodine-129 in groundwater is significant because of its relatively low $(1 \mathrm{pCi} / \mathrm{L})$ drinking water standard, its long-term releases from nuclear fuel processing facilities, and its long half-life (16 million years). Iodine-129 is very mobile in groundwater. Waste containing iodine-129 was historically disposed of in the 200 Areas, and groundwater plumes are similar in shape and extent to the tritium plumes, though concentrations above the drinking water standard have not reached the Columbia River.

Nitrate - Nitrate contamination in the unconfined aquifer reflects the extensive use of nitric acid in decontamination and chemical processing operations. Like tritium, nitrate was present in many waste streams and is mobile in groundwater. Agricultural sources of nitrate are located off the Hanford Site to the south and west. Nitrate was measured at concentrations greater than the maximum contaminant level $(45 \mathrm{mg} / \mathrm{L})$ in wells in all operational areas except 100-B/C Area.

Carbon Tetrachloride - Carbon tetrachloride was used in plutonium processing in the 200 West Area, where concentrations in groundwater exceed the $5-\mu \mathrm{g} / \mathrm{L}$ maximum contaminant level. The plume extends beyond the area boundary and forms the most widespread organic contaminant plume on the Hanford Site. 


\begin{tabular}{|c|c|c|c|}
\hline \multicolumn{4}{|c|}{ Area of Contaminant Plumes at Levels Above Drinking Water Standards (square kilometers) } \\
\hline $\begin{array}{c}\text { Constituent } \\
\text { (drinking water standard) }\end{array}$ & Fiscal Year 2000 & Fiscal Year 2001 & Fiscal Year 2002 \\
\hline Carbon tetrachloride $(5 \mu \mathrm{g} / \mathrm{L})$ & 9.8 & 9.8 & 9.9 \\
\hline Chromium (100 pg/L) & 2.8 & 2.8 & 2.6 \\
\hline lodine-129 (1 pCi/L) & 89.6 & $79.5^{(a)}$ & 79.4 \\
\hline Nitrate (45 mg/L) & 36.3 & 38.4 & 35.7 \\
\hline Strontium-90 (8 pCi/L) & 2.8 & 2.7 & 2.7 \\
\hline Technetium-99 (900 pCi/L) & 2.3 & 2.4 & 2.3 \\
\hline Trichloroethene (5 pg/L) & 4.2 & 4.3 & $3.4^{(a)}$ \\
\hline Tritium $(20,000 \mathrm{pCi} / \mathrm{L})$ & 152 & 151 & 142 \\
\hline Uranium (20/30 pg/L) & 2.0 & 1.6 & 1.5 \\
\hline Combined Plumes & 210 & 208 & 196 \\
\hline
\end{tabular}

Trichloroethene - Trichloroethene was used on the Hanford Site in the 1960s and 1970s as a degreasing compound. The drinking water standard is $5 \mu \mathrm{g} / \mathrm{L}$. The most extensive plume is in the 200 West Area. Trichloroethene also exceeded the standard in the 100-K and 100-F Areas. Concentrations in the 300 and Richland North Areas remained below the standard in fiscal year 2002.

Chromium - A major source for chromium was the sodium dichromate used as a corrosion inhibitor in cooling water for reactors in the 100 Areas. The most significant chromium plumes are located in the 100-K, 100-D, and 100-H Areas.

Strontium-90 - Strontium-90 was present in waste associated with fuel processing. It was released also by fuel element failures during reactor operations. Strontium-90 has a half-life of 28.8 years and a drinking water standard of $8 \mathrm{pCi} / \mathrm{L}$. It moves slowly through the vadose zone and in groundwater. Strontium-90 exceeds the drinking water standard beneath each of the reactor areas, small parts of the 200 Areas, and the former Gable Mountain Pond.

Technetium-99 - Technetium-99 was present in waste streams associated with fuel processing. It has a half-life of 210,000 years and a drinking water standard of $900 \mathrm{pCi} / \mathrm{L}$. Technetium-99 is very mobile in groundwater and concentrations exceed the drinking water standard beneath portions of the 200 Areas.

Uranium - Uranium contamination on the Hanford Site had numerous potential sources including fuel fabrication, fuel processing, and uranium recovery from separations activities. Uranium tended to be associated with technetium-99 through the fuel processing cycle, but uranium is less mobile in groundwater on the Hanford Site. The drinking water standard is $30 \mu \mathrm{g} / \mathrm{L}$. Plumes are detected in the 200 West, 200 East, and 300 Areas.

Carbon-14 - Carbon-14 exceeded the 2,000-pCi/L drinking water standard in two small plumes near waste disposal facilities adjacent to the KW and KE Reactor buildings where reactor atmosphere gas condensate was discharged to the ground in the past. The half-life is 5,730 years.

Cyanide - Cyanide was associated with waste discharged to the BY cribs near 200 East Area. In groundwater, it exceeded the $200-\mu \mathrm{g} / \mathrm{L}$ drinking water standard in two wells near the cribs. 


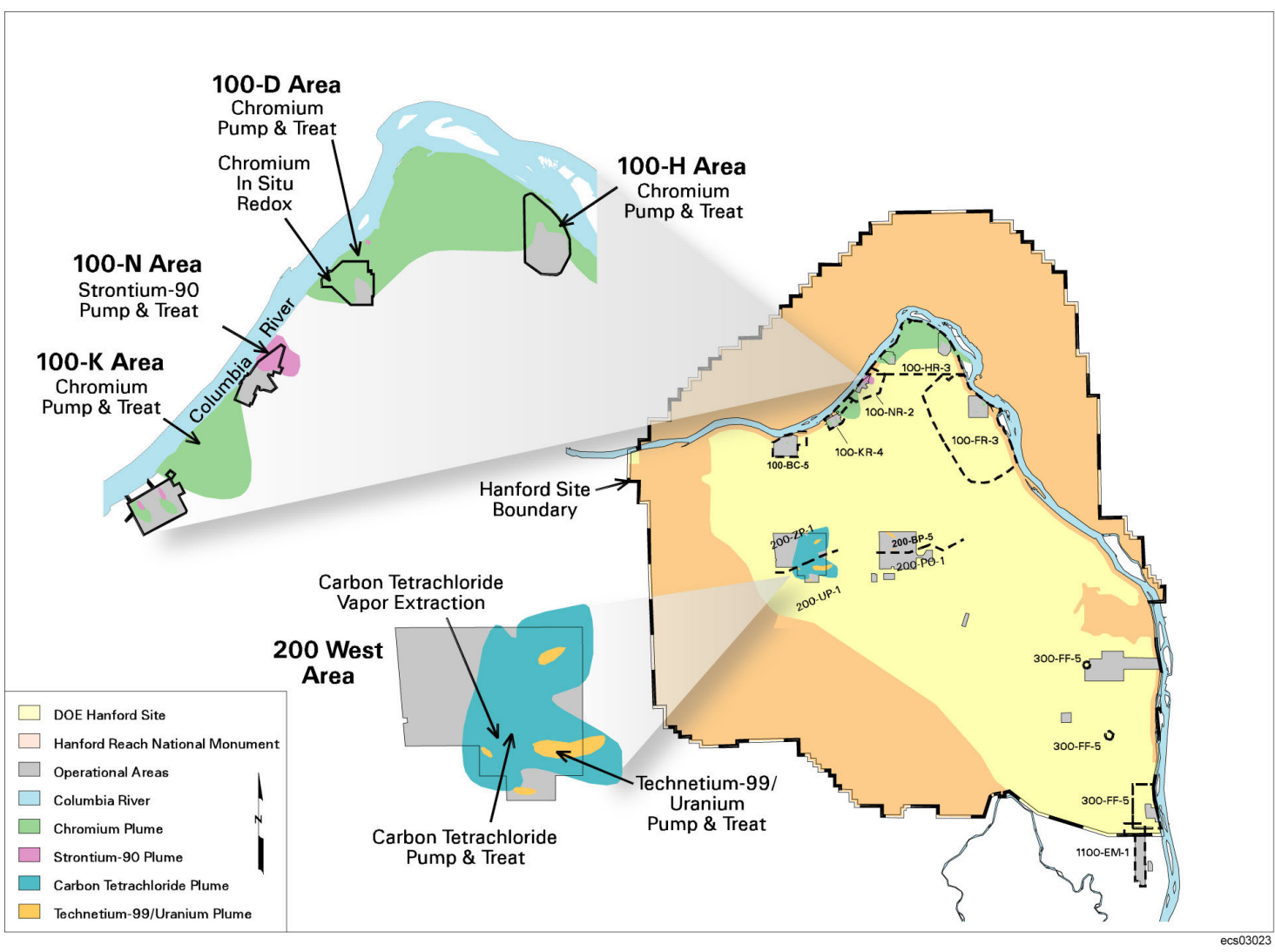

DOE operates five pump-and-treat systems, one in situ remediation system, and one soil-gas extraction system to limit movement of contaminants in groundwater and the vadose zone.

When groundwater is pumped from the subsurface, it is treated to remove contaminants before being discharged. This process is often referred to as a pumpand-treat system. This common form of groundwater remediation is being used at Hanford to remove carbon tetrachloride, chromium, technetium-99, and uranium.
Cesium-137 - Cesium-137 has a half-life of 30 years and a drinking water standard of $200 \mathrm{pCi} / \mathrm{L}$. It was present in waste associated with fuel processing and has been released in reactor areas by fuel element failures. Cesium-137 was present in waste that leaked from underground storage tanks in the past. It is present in the vadose zone near the single-shell tanks, but is detected in groundwater only near the former 216-B-5 injection well in the 200 East Area.

Plutonium - Plutonium was present in waste associated with fuel processing. It has a low mobility in groundwater and a long half-life (24,000 years for plutonium-239 and 6,500 years for plutonium-240). The only significant detection of plutonium in recent years was associated with the 216-B-5 injection well in the 200 East Area.

\section{Groundwater Remediation and Monitoring of CERCLA Operable Units}

DOE monitors groundwater on the Hanford Site to comply with requirements of CERCLA at 11 groundwater operable units. DOE, EPA, and Washington State Department of Ecology determine methods for remediating contaminated groundwater via formal documents called records of decision.

One operable unit, 1100-EM-1 (Richland North Area), has a final record of decision calling for natural attenuation of volatile organic compounds. Groundwater is monitored to determine the success of this approach. In fiscal year 2002, contaminant concentrations remained below their target levels. 
At six of the operable units, interim remedial actions are required until final cleanup decisions are made. DOE monitors groundwater to assess the effectiveness of the interim actions.

- 100-HR-3 (100-D and 100-H Areas) and 100-KR-4 (100-K Area) Chromium may pose a threat to aquatic organisms in the Columbia River. In the 100-K, 100-D, and 100-H Areas, pump-and-treat systems reduce the amount of chromium reaching the river. Also in the 100-D Area, an innovative treatment method, called in situ redox, immobilizes chromium in the aquifer. In fiscal year 2002, chromium concentrations at all these interim action sites remained above cleanup targets.

- 100-NR-2 (100-N Area) - Strontium-90 concentrations remained much higher than the drinking water standard in wells at the river shore in fiscal year 2002. DOE operates a pump-and-treat system for strontium-90 as an interim action. The system continued to divert groundwater flow in fiscal year 2002 but is not an efficient way to clean up the aquifer.

- 200-UP-1 (200 West Area) - An interim record of decision required operation of a pump-and-treat system to reduce technetium-99 and uranium contamination. In fiscal year 2002, some concentrations remained above target levels. Many of the wells monitoring this area have gone dry, so the size of the current plumes is uncertain.

- 200-ZP-1 (200 West Area) - An interim record of decision requires operation of a pump-and-treat system to prevent carbon tetrachloride from spreading. In fiscal year 2002, the system continued to limit migration of the heart of the plume. DOE also is extracting and treating soil gas to remove carbon tetrachloride from the vadose zone. In fiscal year 2002, workers deepened two wells at one site and completed them as soil-gas extraction wells.

Hanford groundwater flows into the Columbia River, which is a major drinking water source. Therefore, DOE is focusing their remediation efforts on protecting the Columbia River.

\begin{tabular}{|c|c|c|}
\hline \multicolumn{3}{|c|}{ Groundwater Remediation } \\
\hline Location & Startup Date & Progress From Startup to September 2002 \\
\hline 100-K Area 100-KR-4 Pump-and-Treat & 1997 & $\begin{array}{l}\text { Decreases chromium to river; } 175 \text { kilograms chromium } \\
\text { removed. }\end{array}$ \\
\hline 100-N Area 100-NR-2 Pump-and-Treat & 1995 & $\begin{array}{l}\text { Diverts strontium- } 90 \text { from river; } 1.3 \text { curies strontium- } 90 \\
\text { removed. }\end{array}$ \\
\hline 100-D Area 100-HR-3 Pump-and-Treat & 1997 & $\begin{array}{l}\text { Decreases chromium to river; } 120 \text { kilograms chromium } \\
\text { removed. }\end{array}$ \\
\hline 100-D Area 100-HR-3 In Situ Redox & 1999 & $\begin{array}{l}\text { Decreases chromium concentration downgradient of } \\
\text { barrier. }\end{array}$ \\
\hline 100-H Area 100-HR-3 Pump-and-Treat & 1997 & $\begin{array}{l}\text { Decreases chromium to river; } 34 \text { kilograms chromium } \\
\text { removed. }\end{array}$ \\
\hline 200 West Area 200-ZP-1 Pump-and-Treat & 1994 & $\begin{array}{l}\text { Prevents high-concentration portion of carbon tetrachlo- } \\
\text { ride plume from spreading; } 6,874 \text { kilograms removed. }\end{array}$ \\
\hline 200 West Area Soil-Vapor Extraction & 1992 & $\begin{array}{l}\text { Prevents carbon tetrachloride movement to ground- } \\
\text { water; } 77,800 \text { kilograms removed from vadose zone. }\end{array}$ \\
\hline 200 West Area 200-UP-1 Pump-and-Treat & 1994 & $\begin{array}{l}\text { Decreases migration of contaminants; } 90 \text { grams } \\
\text { technetium- } 99,158 \text { grams uranium, } 23 \text { kilograms } \\
\text { carbon tetrachloride, and 23,200 kilograms nitrate } \\
\text { removed. }\end{array}$ \\
\hline 300-FF-5 Natural Attenuation & $\begin{array}{l}\text { Not } \\
\text { applicable }\end{array}$ & $\begin{array}{l}\text { Trichloroethene concentrations below target level; } \\
\text { uranium concentrations above target level. }\end{array}$ \\
\hline $1100-E M-1$ Natural Attenuation & $\begin{array}{l}\text { Not } \\
\text { applicable }\end{array}$ & $\begin{array}{l}\text { Trichloroethene concentrations below } 5-\mu g / \mathrm{L} \text { in } 2001 \\
\text { and } 2002 .\end{array}$ \\
\hline
\end{tabular}


- 300-FF-5 (300 Area and satellite areas to the north) - An interim record

Monitoring well networks are designed specifically for individval areas based on the type of data needed, the hydrogeologic conditions, geologic conditions, groundwater flow directions, and the expected contaminants. of decision calls for monitoring the cis-1,2-dichloroethene, trichloroethene, and uranium plumes. In fiscal year 2002, concentrations of the organic contaminants were low, but uranium remained elevated.

At four operable units, there is no imminent threat to human health or the environment; therefore, no interim remedial actions are required. These operable units include 100-BC-5 (100-B/C Area), 100-FR-3 (100-F Area), 200-BP-5, and 200-PO-1 (200 East Area). Waste sites and plumes will continue to be monitored until there are final records of decision.

\section{Areas Groundwater Contamination}

During 1944 to 1988, fabricated fuel cylinders were shipped by rail from the 300 Area to the reactors in the 100 Areas for irradiation, the second step in the plutonium production process. The nine plutonium production reactors are $\sim 30$ miles from Richland in the northern portion of the Hanford Site along the south bank of the Columbia River. The reactor areas had to be close to the river because large quantities of water were required for cooling.

Today, the most prominent contaminants in 100 Areas groundwater are tritium, strontium-90, hexavalent chromium, and nitrate. These contaminants originated from disposal cribs, trenches, and leaking retention basins. Because these sites are so close to the Columbia River, all of these contaminants have been detected in springs that discharge to the river.

100-B/C Area - Most of the groundwater contamination in the 100-B/C Area is found in the north portion of the area, beneath waste trenches and retention
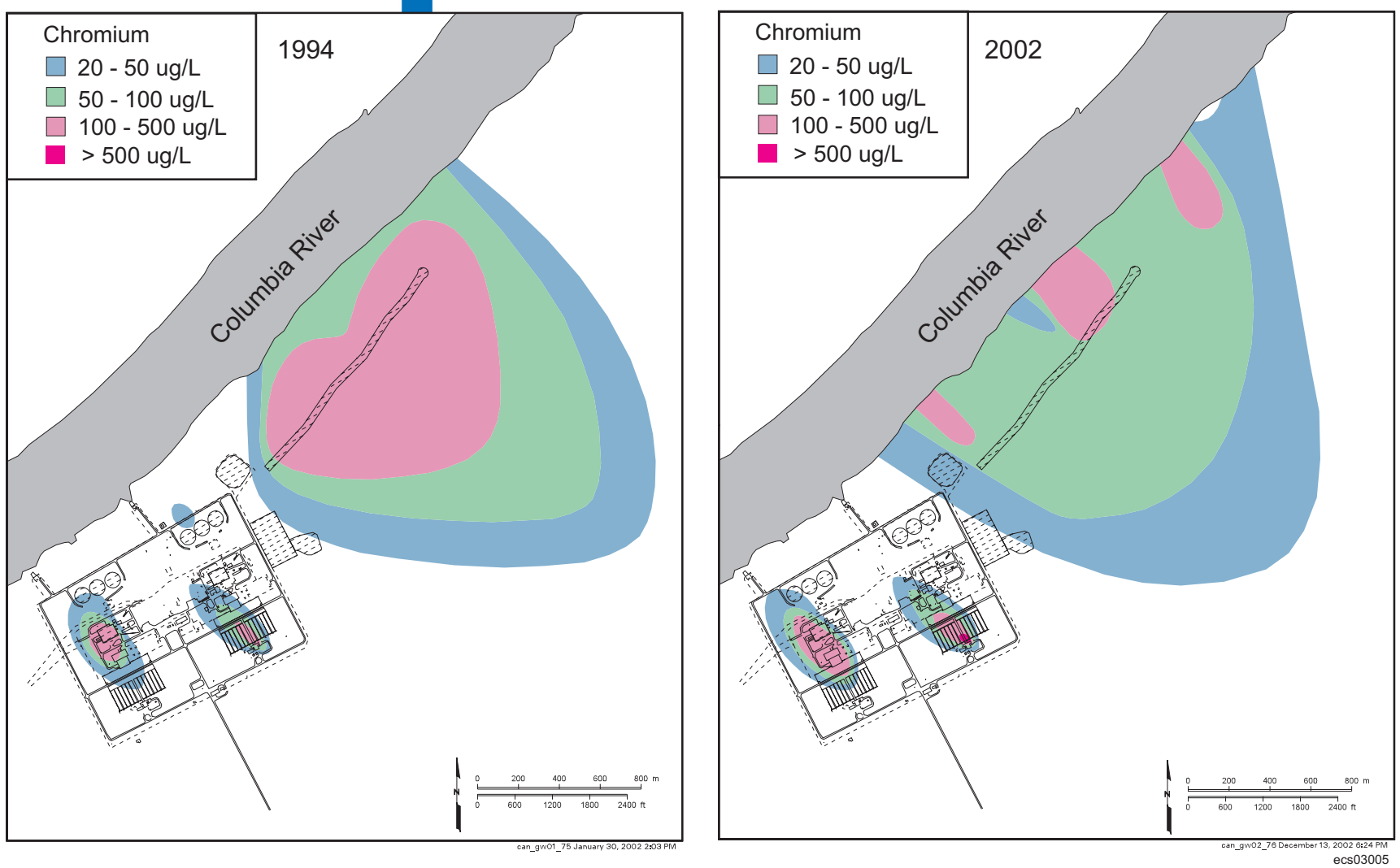

A pump-and-treat system in the 100-K Area reduces the amount of chromium entering the Columbia River. The shape of the plume has remained fairly stable since 1994 but concentrations decreased in some areas. 
basins. Tritium and strontium-90 exceeded drinking water standards in several wells. Nitrate and chromium were somewhat elevated, but were below drinking water standards in fiscal year 2002. Surface waste sites have been excavated and backfilled. There is no active groundwater remediation in the 100-B/C Area.

100-K Area - The primary constituents of interest in 100-K Area groundwater are hexavalent chromium and tritium. Other groundwater contaminants include carbon-14, nitrate, and trichloroethene. The major chromium plume is beneath the 116-K-2 trench, located east of 100-K Area near the Columbia River. This plume is the target of a pump-and-treat system that reduces contaminated flow into the river.

High concentrations of tritium in very small plumes originated from past leaks in fuel storage basins and waste disposal sites near the KE Reactor building. The average concentration in fiscal year 2002 was $460,000 \mathrm{pCi} / \mathrm{L}$, but no new leaks were detected. Contractors continued to remove the spent fuel from the KE fuel storage basins in 2002.

In recent years, tritium contamination was detected in a monitoring well near the 118-K-1 burial ground. Results of a study published in 2002 suggest that the tritium is from a previously unidentified plume that may be related to former disposal of tritium-producing irradiated metallic waste in the burial ground.

100-N Area - The primary groundwater contaminant in this area is strontium-90. The plume originated at two liquid waste disposal cribs. The extent of the plume changed very little in over 12 years; however, concentrations increased during the 1990s because of changing water levels and the end of effluent discharge. A pump-and-treat system in the 100-N Area operates to reduce the movement of strontium-90 toward the Columbia River. Since strontium-90 binds to sediment grains, pump-and-treat is not an effective way to clean up the aquifer. Tritium also
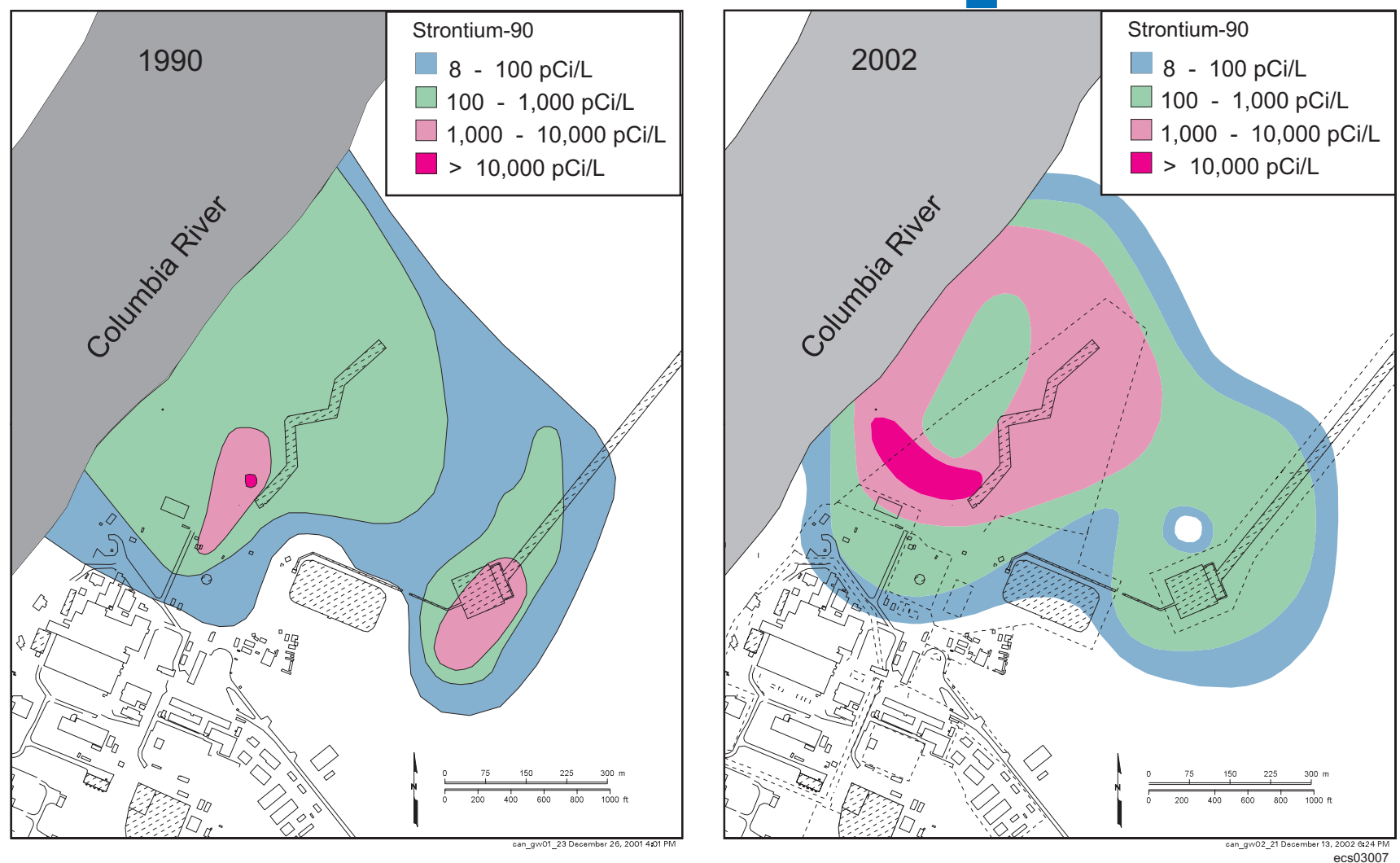

Concentrations of strontium-90 in the 100-N Area increased after 1990, but the overall shape of the plume remained about the same in 2002. 

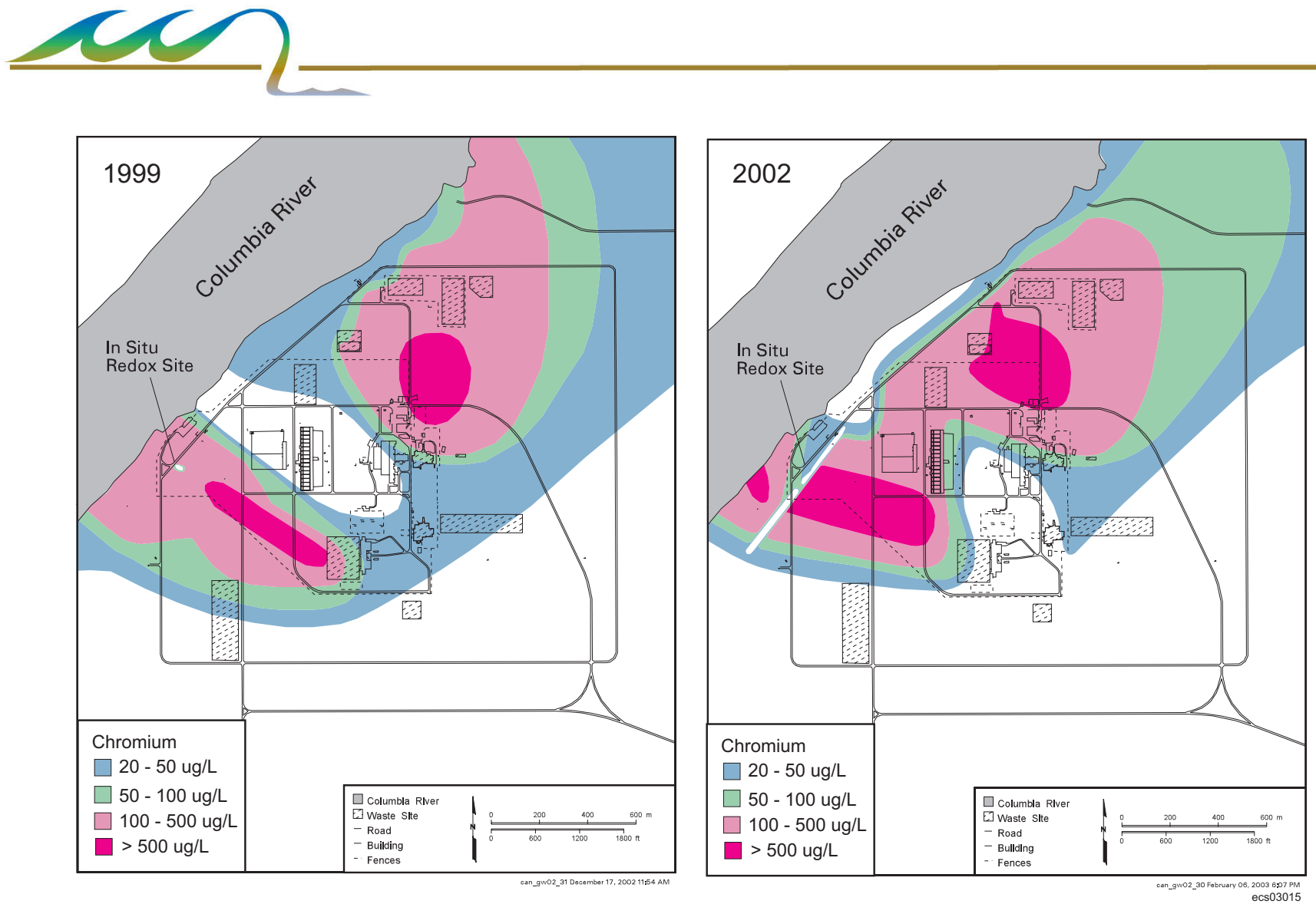

The shape of the chromium plume in the 100-D Area has changed since 1999. Plumes from two chromium sources have moved into the central 100-D Area and merged. The north plume is the target of a pump-and-treat system and the southwest plume is being treated within the aquifer.
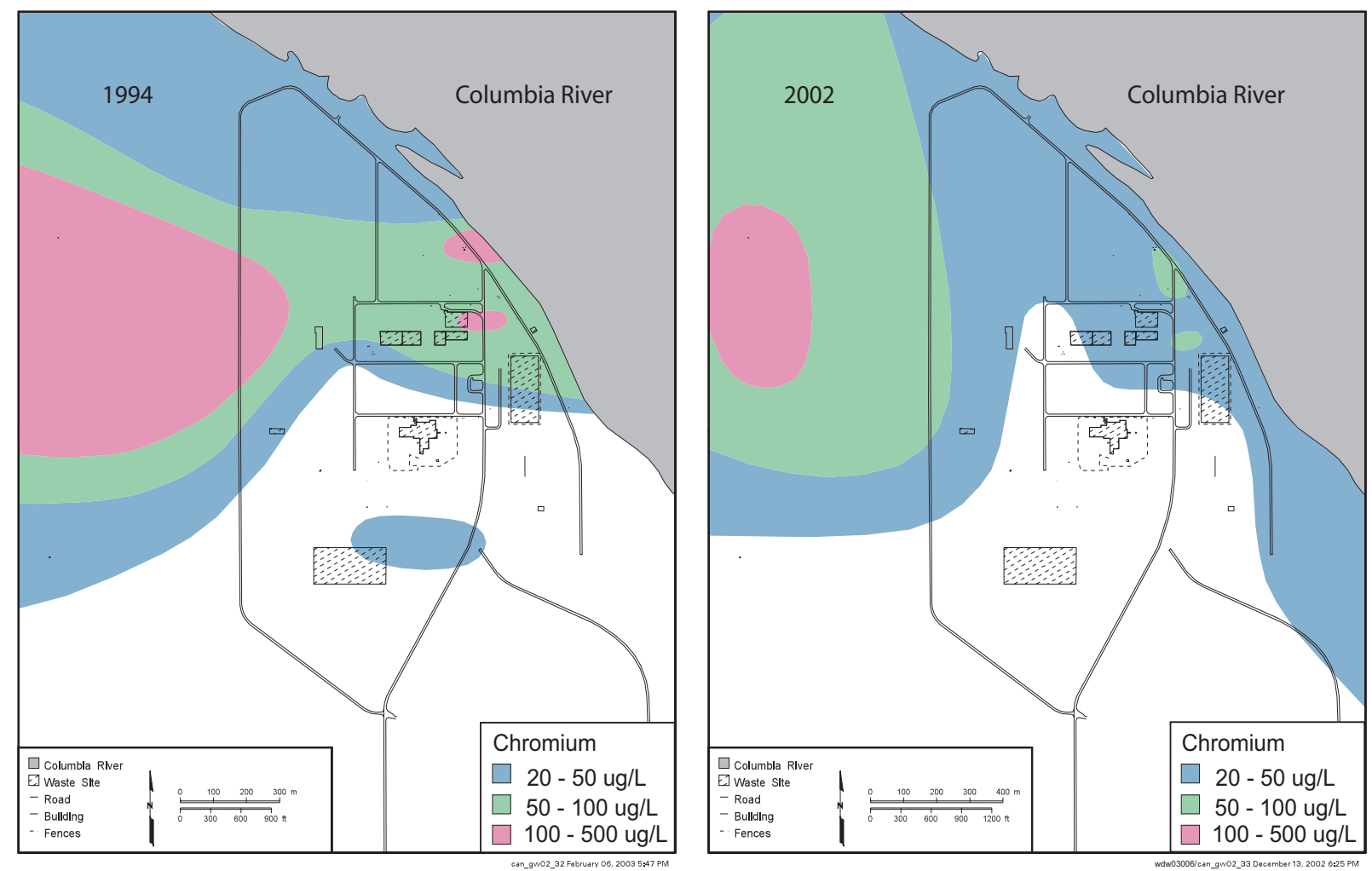

A pump-and-treat system in the $100 \mathrm{H}$-Area reduces the amount of chromium entering the Columbia River. Between 1994 and 2002, concentrations decreased through most of the plume. Much of the decrease appears to be due to natural processes. 
was present in waste discharged to the $100-\mathrm{N}$ cribs. Tritium concentrations in groundwater are declining, and the plume is shrinking. Nitrate, sulfate, and petroleum hydrocarbons also are present in 100-N Area groundwater. The 116-N-1 crib was excavated in fiscal year 2002 to remove contaminated sediment near the surface.

100-D Area - Hexavalent chromium is the primary contaminant of concern in the 100-D Area. The source of this contaminant was sodium dichromate added to cooling water to inhibit corrosion. The water was discharged to cribs and ditches, and some spillage of sodium dichromate also occurred. Hexavalent chromium is highly mobile in groundwater. Chromium is distributed in two plumes that are merging. The north plume is the target of a pump-and-treat system for the 100-HR-3 Operable Unit, which also includes the 100-H Area. The southwest chromium plume is being remediated with an in situ system that immobilizes chromium in the aquifer. This plume had the highest chromium concentrations on the Hanford Site in fiscal year 2002, with an average concentration over 3,000 $\mu \mathrm{g} / \mathrm{L}$.

100-H Area - Hexavalent chromium is present in 100-H Area groundwater, but the plume is smaller and concentrations are lower than in the 100-D Area. The plume is intercepted by pumping wells, treated, and the treated water is injected into an upgradient location. Chromium concentrations have decreased in recent years. Nitrate also is elevated, but concentrations have declined from their peaks. Strontium-90 exceeds the drinking water standard beneath former retention basins. Technetium-99 and uranium are elevated in a small area but were below their drinking water standards in fiscal year 2002.

100-F Area - Nitrate exceeds the drinking water standard beneath much of the 100-F Area and the downgradient region. Strontium-90 exceeds the drinking water standard in a small plume beneath former waste sites in the eastern 100-F Area, near the Columbia River. There also is a small plume of trichloroethene at concentrations above the maximum contaminant level. Excavation of former waste sites continued in fiscal year 2002. There is no active groundwater remediation in the $100-\mathrm{F}$ Area.

\section{Areas Groundwater Contamination}

After fuel rods were irradiated in the 100 Areas, they were shipped to the 200 Areas. There, between 1944 and 1987, separations (finishing) plants processed the fuel to extract and purify plutonium. The plutonium extraction first took place at the $\mathrm{T}$ and $\mathrm{B}$ plants and later at the Reduction-Oxidation (REDOX) and PUREX Plants. The Plutonium Finishing Plant was used for plutonium purification. U Plant was used to extract uranium from process waste and T Plant was converted to an equipment decontamination facility. Currently, the 200 Areas are used for waste management and disposal.

The 200 Areas are located 20 miles from Richland on a plateau in the center of the Hanford Site, $\sim 5$ miles south of the Columbia River. During the finishing process, contaminants such as carbon tetrachloride, chromium, fluoride, iodine-129, nitrate, technetium-99, trichloroethene, tritium, and uranium were disposed to the ground in the 200 Areas. This contamination has moved into the vadose zone and is responsible for groundwater contamination currently detected at these sites.

Radioactive and hazardous chemical waste generated from plutonium production and separation activities historically was stored in single-shell tanks in the 200 Areas. These underground tanks were constructed of reinforced concrete and steel in the 1940s. Although most of the free liquid has been removed, some of these tanks leaked in the past and appear to have contributed to groundwater contamination. The tanks still contain $\sim 87$ million liters of highly caustic saltcake
Groundwater from the Hanford Site can reach the Columbia River in days, months, or years depending on the geology and how far it has to travel. During this time, many of the contaminants are decreased by natural decay. 

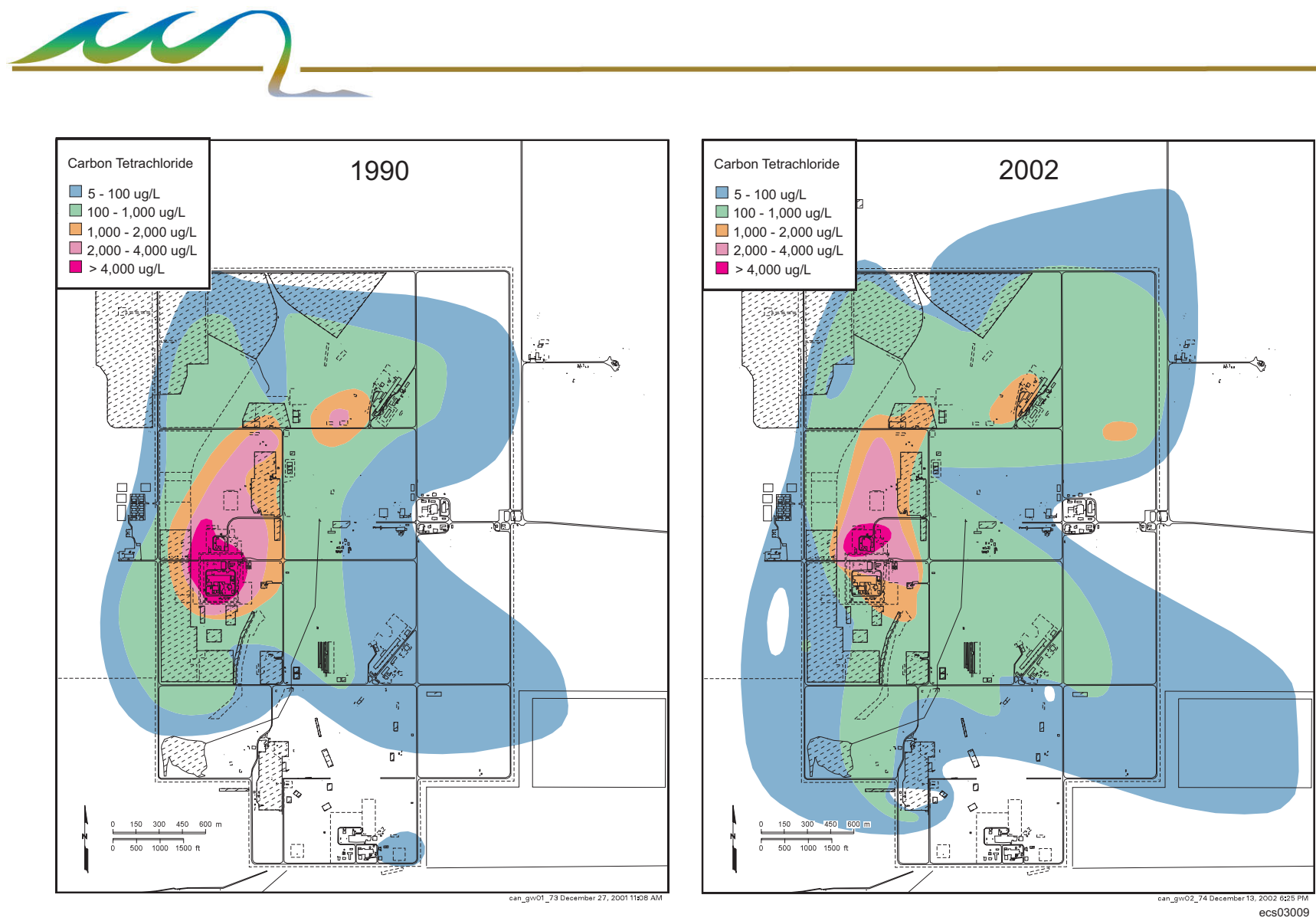

The carbon tetrachloride plume beneath the 200 West Area spread between 1990 and 2002. Since 1996, a pumpand-treat system is helping prevent further spreading of the heart of the plume, shown here in pink and red.

Pump-and-treat systems in the 200 West Area are interim actions for groundwater remediation until a final remedy can be identified. and 45 million liters of chemical sludge. The tanks are grouped into farms that are regulated under RCRA and monitored to detect new leaks or to define the extent of contamination.

200 West Area - The aquifer beneath the 200 West Area has a lower permeability than beneath the 200 East or 100 Areas, which slows contaminant movement.

The largest plume of chlorinated hydrocarbons on the Hanford Site is beneath the 200 West Area and includes carbon tetrachloride, chloroform, and trichloroethene. The contamination is principally from waste disposal operations associated with the Plutonium Finishing Plant, where organic chemicals were used in plutonium processing. A groundwater pump-and-treat system is operating in this area to prevent the spread of the central, high-concentration portion of the carbon tetrachloride plume.

In some areas, concentrations of carbon tetrachloride decrease with depth, but at some locations carbon tetrachloride is present at higher concentrations deeper in the Hanford/Ringold sediment than at the water table. Therefore, the extent of the plume at the water table may not reflect the extent in deeper parts of the aquifer system.

The 200 West Area also contains plumes of technetium-99 and uranium from sources near T Plant and U Plant and single-shell tank farms. A groundwater pumpand-treat system is operating near $U$ Plant to contain the technetium-uranium plume there. Contaminant concentrations have declined, and the plumes have shrunk, apparently as a result of remediation and dispersion.

The highest tritium concentrations in the 200 West Area are detected beneath waste facilities associated with $\mathrm{T}$ Plant. The maximum concentration detected in fiscal year 2002 was 1.7 million $\mathrm{pCi} / \mathrm{L}$, the same as in fiscal year 2001. A larger 

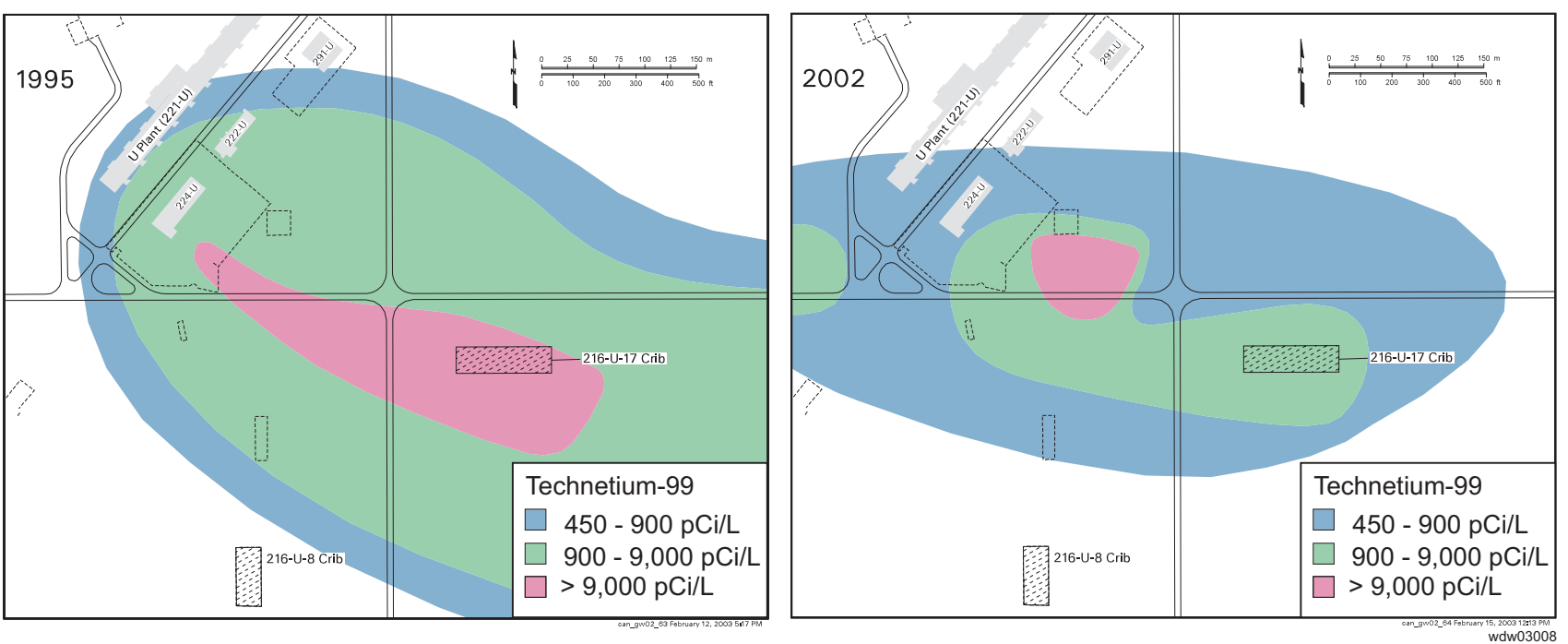

A pump-and-treat system at the 200-UP-1 Operable Unit (200 West Area) has decreased the size of the technetium-99 plume. The system began to operate in fall 1995. However, many monitoring wells in the plume have gone dry, making interpretation of plume size less certain.
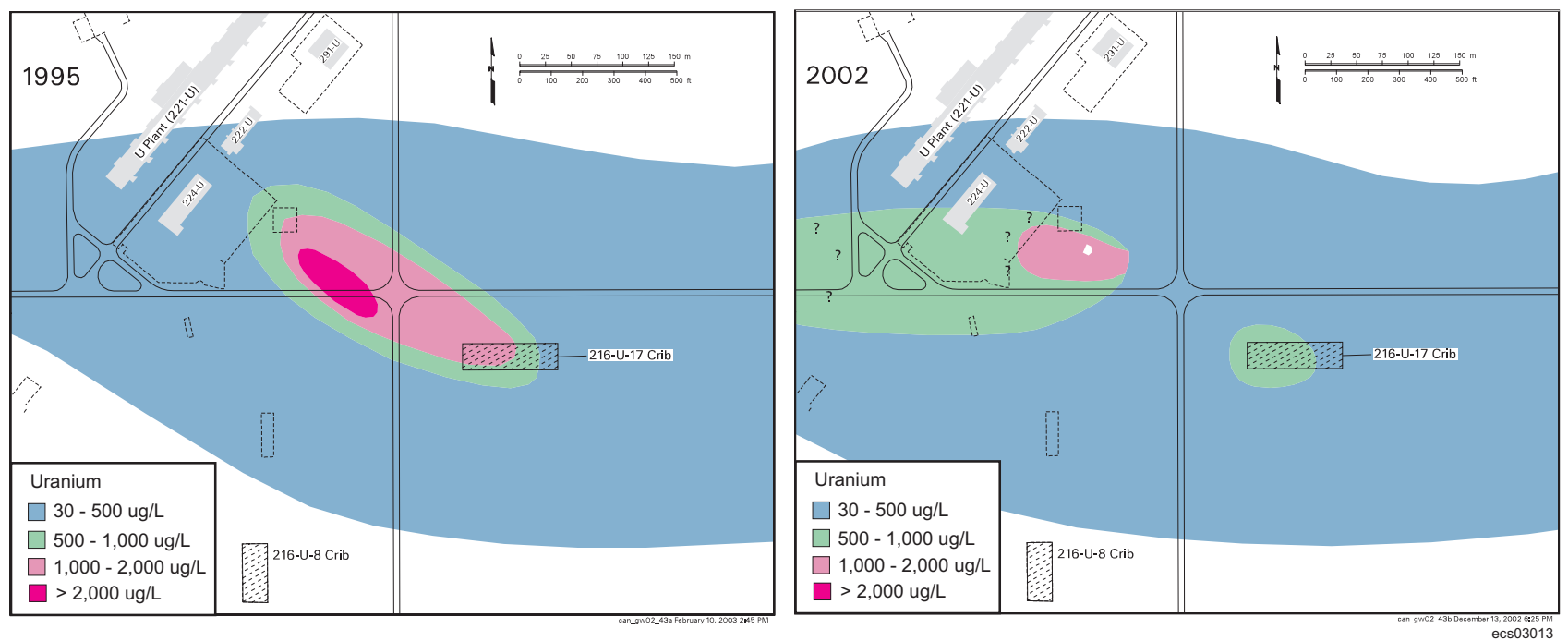

Uranium contamination in the 200-UP-1 Operable Unit (200 West Area) is not responding to the pump-and-treat system as quickly as the technetium-99. Unlike technetium, uranium interacts with sediment grains, slowing its movement and response to remediation.

plume (with lower concentrations) originated at sites associated with the REDOX Plant in the southeast part of the 200 West Area. It is slowly moving eastward with groundwater flow. Smaller tritium plumes are detected beneath a former waste site in the southwest part and near an active disposal site north of 200 West Area.

Iodine-129 plumes coincide generally with the tritium plumes associated with the T Plant and REDOX Plant. The maximum concentration in fiscal year 2002 in this region was $32 \mathrm{pCi} / \mathrm{L}$.

The 200 West Area has two main nitrate plumes: one from the vicinity of U Plant extending into the 600 Area and another near T Plant. Lower concentrations of contamination are found near the Plutonium Finishing and REDOX Plants. 

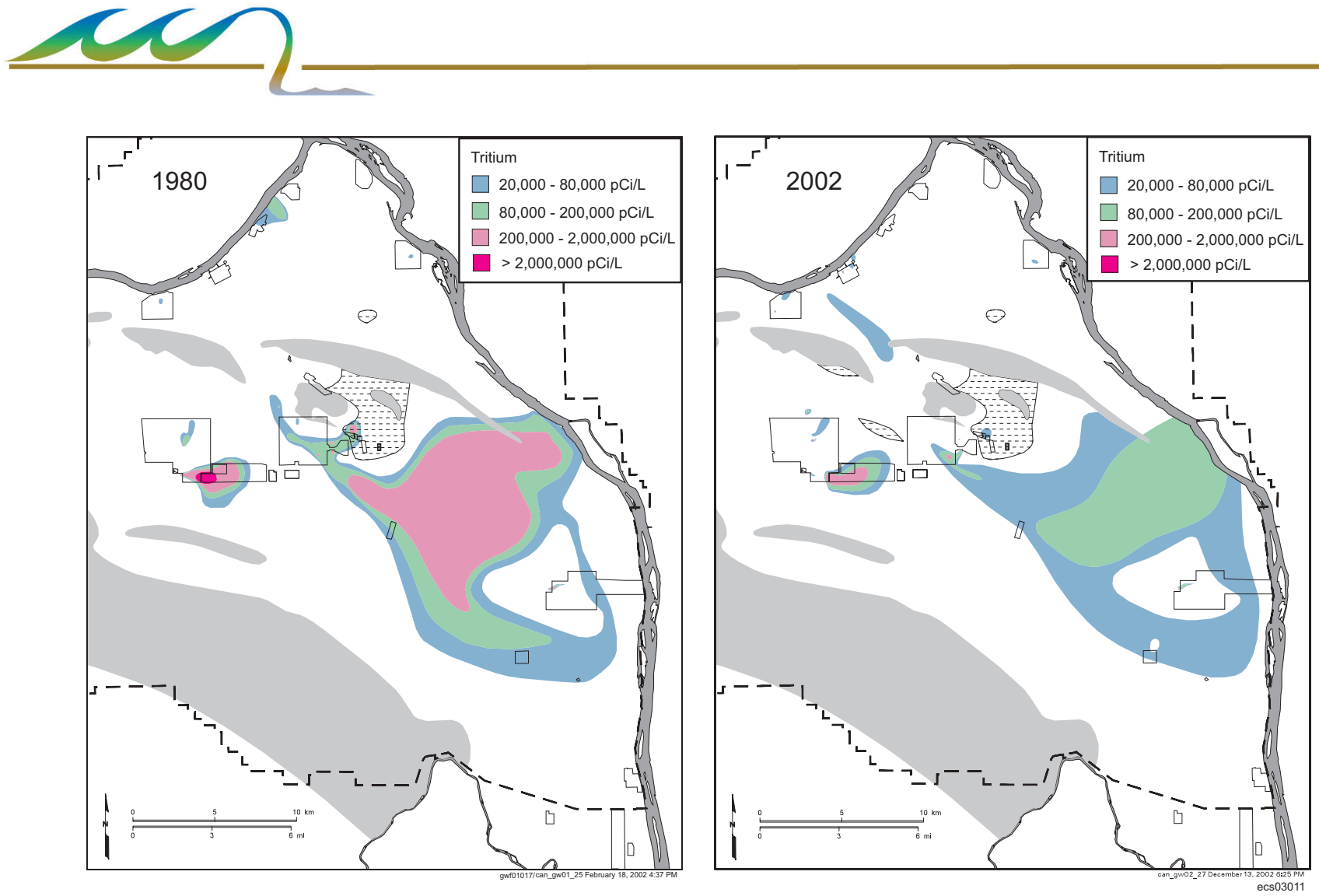

Tritium plumes in 1980 and 2002 at the 200 East Area are shown in the above maps. Concentrations in the heart of the plume have decreased over the years; in approximately 1995, the south margin appears to have ceased its southward migration.

Tritium is very mobile in groundwater and has migrated from sources in the 200 Areas toward the southeast and the Columbia River.
Chromium and fluoride exceeded maximum contaminant levels in several wells near T, TX, and TY Tank Farms. The plumes are not widespread.

Strontium-90 has been detected in very small areas near facilities that received waste from the REDOX Plant. In fiscal year 2002, only one well had concentrations exceeding the drinking water standard.

200 East Area - Disposal of liquid waste in the 200 East Area has contaminated groundwater with tritium, iodine-129, nitrate, and several other contaminants. The most widespread and mobile contaminants have flowed through the permeable aquifer to the Columbia River.

The largest tritium plume originated at waste sites near the PUREX Plant in the southeast 200 East Area. Concentrations in one well near the former waste sites were up to 4.2 million $\mathrm{pCi} / \mathrm{L}$ in fiscal year 2002, which is slightly lower than the highest concentration the previous year.

The movement of the PUREX tritium plume can be traced with historical groundwater data. By 1980, tritium concentrations above $20,000 \mathrm{pCi} / \mathrm{L}$ had reached the Columbia River at the Hanford town site. In the south portion of the Hanford Site, the $20,000-\mathrm{pCi} / \mathrm{L}$ portion of the plume had apparently flowed around less transmissive sediment beneath the Energy Northwest location. The core of the plume (concentrations $>200,000 \mathrm{pCi} / \mathrm{L}$ ) had broken off from the source in the southeast 200 East Area. These high concentrations decreased in the past 20 years and are not seen on the map for fiscal year 2002. The south margin of the plume ceased its southward migration in $\sim 1995$. Concentrations in the southeast part of the plume are expected to keep declining because of dispersion and radioactive decay. Concentrations also have declined in the past 10 years in the northwest 200 East Area, but a plume with its origins in that region has migrated north. 

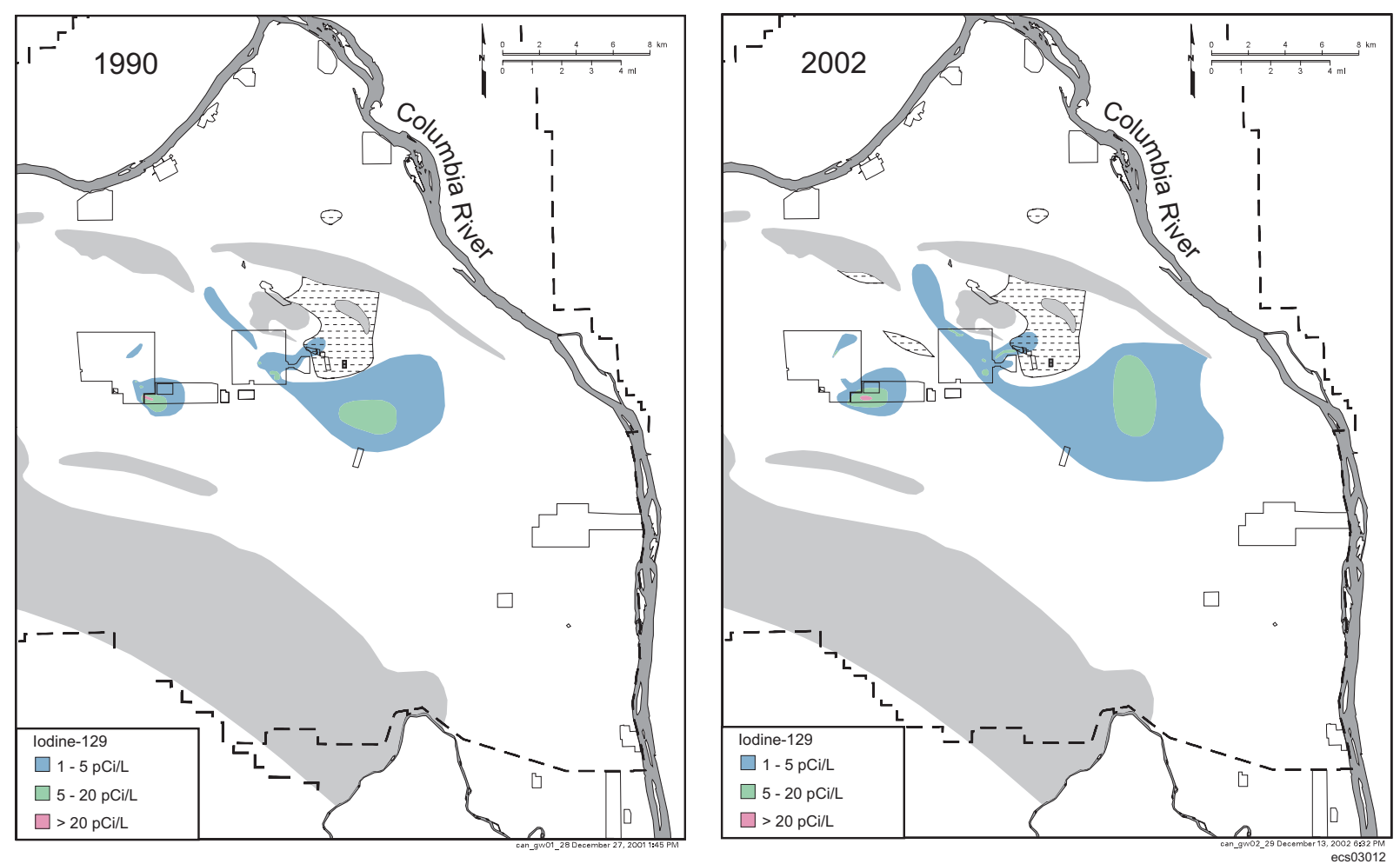

The iodine-129 plume in the 200 East Area (shown on the above maps) moves similarly to the tritium plume, but it has not moved as far. The plumes have spread between 1990 and 2002.

The iodine-129 plume originating in the 200 East Area is similar to the tritium plume, but concentrations greater than the drinking water standard have not reached the Columbia River. The iodine-129 plume from 200 East Area probably migrated at about the same rate as the tritium plume, but iodine-129 data were not commonly collected until the 1980s. By 1990, the portion of the plume exceeding the $1-\mathrm{pCi} / \mathrm{L}$ drinking water standard had traveled more than halfway to the Columbia River. It moved an additional 4 kilometers between 1990 and 2002. The plume will continue moving toward the river, but concentrations are expected to decline because of dispersion.

Waste sites near the PUREX Plant in the 200 East Area contributed to extensive nitrate plumes that extend to the southeast, but only proportionally small areas contain nitrate at levels above the maximum contaminant level. This plume extends to wells near the Columbia River at the Hanford town site, where nitrate concentrations are below the maximum contaminant level and are gradually declining. Another nitrate plume originated from sites in the northwest 200 East Area and spread northward between Gable Butte and Gable Mountain.

Elevated technetium-99 levels are associated with the BY cribs in the northwest 200 East Area. Past leaks from the B-BX-BY single-shell tank farms also appear to be a source of technetium-99 in this area. This plume has migrated toward the north. A less extensive plume of uranium is also present in this vicinity.

The former 216-B-5 injection well in the northwest 200 East Area contaminated groundwater with radionuclides including cesium-137, plutonium, and strontium-90. The residual contamination is very localized.

Other groundwater contaminants in the 200 East Area include cobalt-60 and cyanide near the BY cribs in the northwest part, and strontium- 90 beneath the former Gable Mountain Pond.

lodine-129 flows with tritium toward the Columbia River. 


\section{Area Groundwater Contamination}

The 400 Area is the location of the Fast Flux Test Facility, the largest test reactor on the Hanford Site. DOE has decided to deactivate the facility. The reactor was designed to test fuels and materials for advanced nuclear power plants as well as for the irradiation testing of fuels, core components, and target assemblies for liquid metal fast breeder reactors. Nitrate is the only groundwater contaminant attributable to 400 Area operations. The contamination is believed to have come from a sanitary sewage lagoon that is no longer in use. Nitrite also is detected in groundwater, but concentrations are below the maximum contaminant level.

\section{Area Groundwater Contamination}

In some areas, DOE and the regulators agree that natural processes will clean up groundwater contamination. For example, dispersion (spreading) and radioactive decay decrease concentrations, while bacteria destroy other types of contaminants. Groundwater is monitored throughout the process to determine if concentrations are falling, as expected. This approach is known as monitored natural attenuation and is being applied in the 300 and Richland North Areas.
During years of production, the 300 Area was where uranium fuel was manufactured before it was sent for irradiation in the reactors in the 100 Areas. The 300 Area was also the location of several test reactors during the Manhattan Project and Cold War periods. During the production process, contaminants such as uranium and trichloroethene were discharged to the ground. These elements, along with breakdown products of trichloroethene, are detected in groundwater, but concentrations are decreasing.

An area of elevated uranium concentrations is detected in the 300 Area, downgradient of the $316-5$ process trenches and ponds. Uranium contamination is moving from the vicinity of the process trenches toward the southeast, entering the Columbia River. The most heavily contaminated sediment has been removed.

A plume of trichloroethene in the 300 Area is attenuating naturally, and concentrations remained below the $5-\mu \mathrm{g} / \mathrm{L}$ maximum contaminant level in fiscal year 2002. Bacteria naturally present in the subsurface break down the trichloroethene in this area. This degradation produces cis-1,2-dichloroethene as a byproduct, and this contaminant exceeded the maximum contaminant level in a well that monitors the bottom of the unconfined aquifer in fiscal year 2002.

Tritium from the 200 East Area has migrated into the 300 Area at levels below the drinking water standard. The plume has ceased spreading southward.

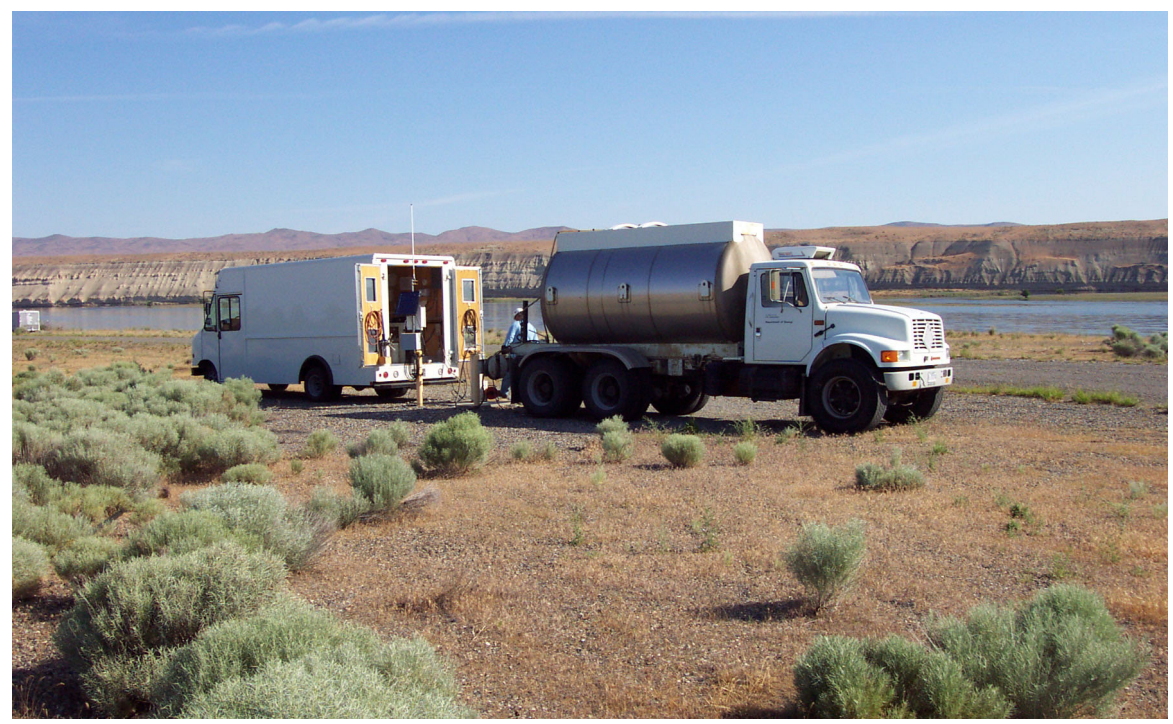

Groundwater monitoring relies on samples from wells across the Hanford Site. This photo shows the sampling vehicle and purgewater collection truck used to sample a well along the Columbia River. 


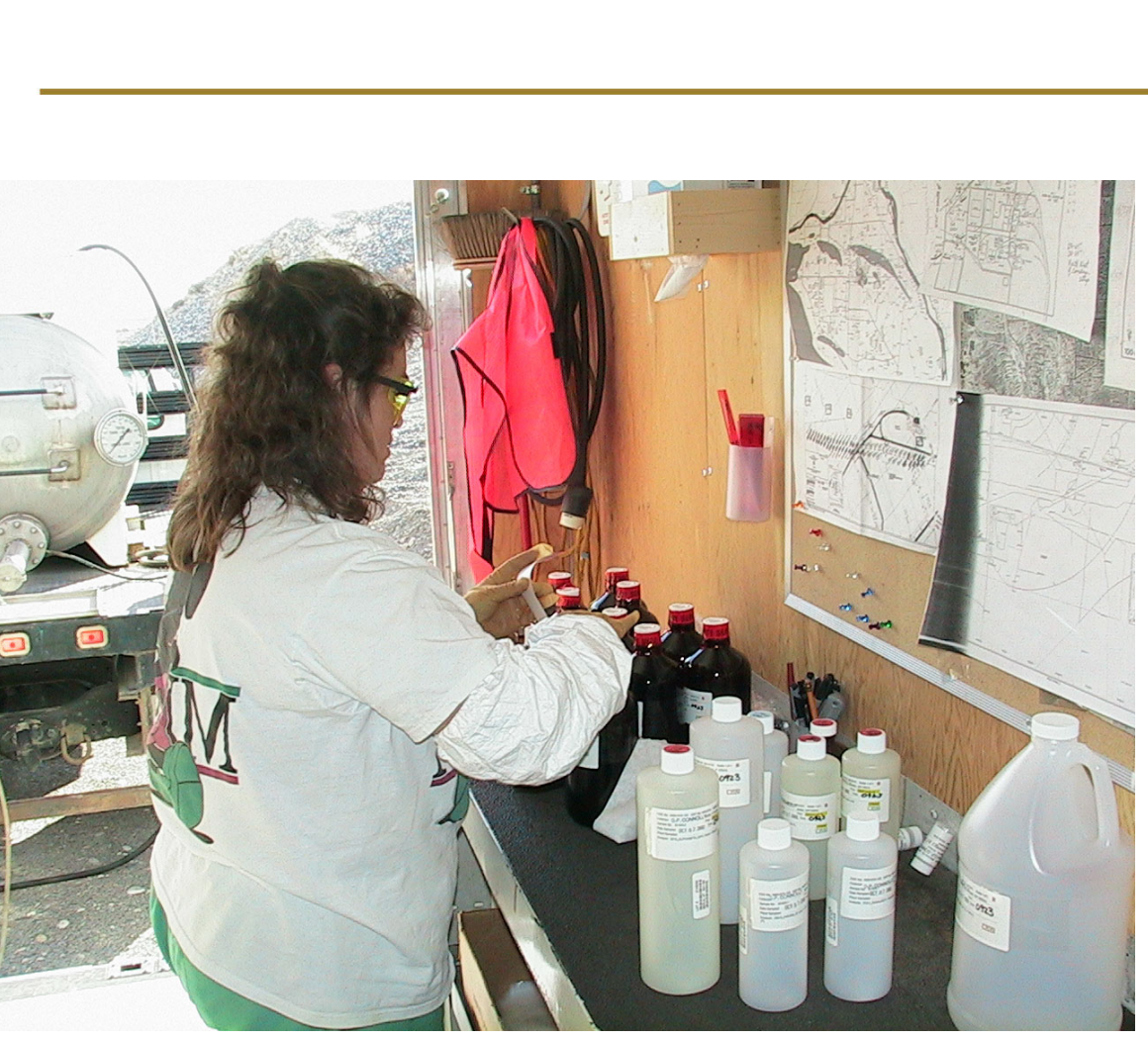

Technicians collect groundwater samples and prepare them for transport to an analytical laboratory, as shown above. The types of bottles used are determined by the type of contaminant that is being investigated.

Strontium-90 concentrations are elevated in one well in the 300 Area but remained below the drinking water standard in fiscal year 2002.

The 300-FF-5 Operable Unit includes two "satellite areas" north of the 300 Area proper. These include the 618-11 burial ground, located near Energy Northwest, where the highest tritium concentrations currently in Hanford Site groundwater have been detected. Concentrations in the most-contaminated well reached 4 million $\mathrm{pCi} / \mathrm{L}$ in fiscal year 2002, down from 8 million $\mathrm{pCi} / \mathrm{L}$ the previous year. Monitoring of nearby wells and soil-gas testing indicate that the contamination is not widespread. The other satellite area includes the 618-10 burial ground and $316-4$ cribs. Groundwater near these facilities is contaminated with uranium and hydrocarbons.

\section{Richland North Area Groundwater Contamination}

The Richland North Area, located just south of the Hanford Site, contained site support services, such as general stores, shipping, receiving, transportation, maintenance, and general warehouse facilities. In 1998, DOE transferred ownership of portions of the Hanford Site located in the Richland North Area to the Port of Benton.

Groundwater beneath a portion of the Richland North Area is designated the 1100-EM-1 Operable Unit, which contains DOE's inactive Horn Rapids Landfill. A small, narrow plume of trichloroethene, which underlies the landfill and Framatome ANP Richland, Inc. (formerly Siemens Power Corporation), is attenuating naturally. Levels declined below the maximum contaminant level of $5 \mu \mathrm{g} / \mathrm{L}$ in fiscal year 2001 and remained below that level in fiscal year 2002. Contaminants also flow into the Richland North Area from offsite sources (i.e., nitrate from agriculture practices, fluoride, ammonia, and gross alpha from Framatome ANP Richland, Inc.). 
The Comprehensive Environmental Response, Compensation, and Liability Act of 1980 (CERCLA) regulates cleanup of waste sites that were active before RCRA took effect. It covers sites where radioactive or hazardous waste were disposed or leaked, and also requires groundwater monitoring where appropriate.
The city of Richland monitors groundwater downgradient of its sanitary landfill, located west of the Richland North Area. Chlorinated hydrocarbons were detected at concentrations above their maximum contaminant levels in fiscal year 2002. Levels were undetected in the nearest well on the Hanford Site.

The city of Richland maintains a well field in the Richland North Area. Wells are monitored frequently to detect any changes in Hanford contaminants near these wells. The tritium plume from the 200 East Area has not been detected in these wells. Low levels of tritium, similar to Columbia River water, continue to be detected.

\section{Upper Basalt-Confined Aquifer}

Although most of Hanford's groundwater contamination is in the unconfined aquifer, DOE monitors wells in the deeper, basalt-confined aquifer because of the potential for downward migration of contamination from the unconfined aquifer and the potential migration of contamination offsite through the confined aquifer. Wells are sampled every three years and most were not sampled in fiscal year 2002 (next scheduled in fiscal year 2003).

\section{Groundwater Monitoring of RCRA Treatment, Storage, and Disposal Units}

DOE monitors groundwater on the Hanford Site to meet the requirements of the RCRA at 24 waste management areas. Fifteen are monitored under indicator evaluation (or detection) programs and do not appear to affect groundwater with hazardous constituents. The others are monitored under assessment or correctiveaction programs. The following list gives specific highlights:

- 116-H-6 evaporation basins (100-H Area) - RCRA monitoring continued during operation of the 100-HR-3 chromium pump-and-treat system. Leakage from the basins in the past contaminated the groundwater with chromium, nitrate, technetium-99, and uranium. The CERCLA program directs corrective action.

- 116-N-1 liquid waste disposal facility (100-N Area) - The indicator parameter $\mathrm{pH}$ fell below its critical range in one downgradient well. This did not indicate contamination from the facility, but was related to chemical effects from a petroleum-contamination site near the well.

- 216-B-3 pond (200 East Area) - DOE initiated a two-year demonstration of an alternative statistical method for indicator evaluation monitoring at this site in fiscal year 2002.

- 216-S-10 pond and ditch (200 West Area) - This site continues to be monitored by just one downgradient and one upgradient well. The other wells in the network have gone dry.

- 216-U-12 crib (200 West Area) - Assessment monitoring continued to indicate that the crib has contributed to a nitrate plume. The monitoring network contains just two useable downgradient wells and no upgradient wells.

- 316-5 process trenches (300 Area) - The monitoring network was revised in fiscal year 2002 as described in a new, corrective-action monitoring plan. This plan implements a two-year demonstration of an alternative statistical method. The trenches and other nearby sources contaminated groundwater with cis-1,2-dichloroethene, trichloroethene, and uranium. Corrective action involves natural attenuation of the contaminants. Concentrations of trichloro-

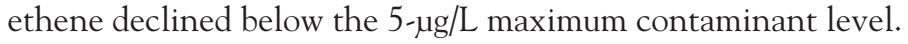




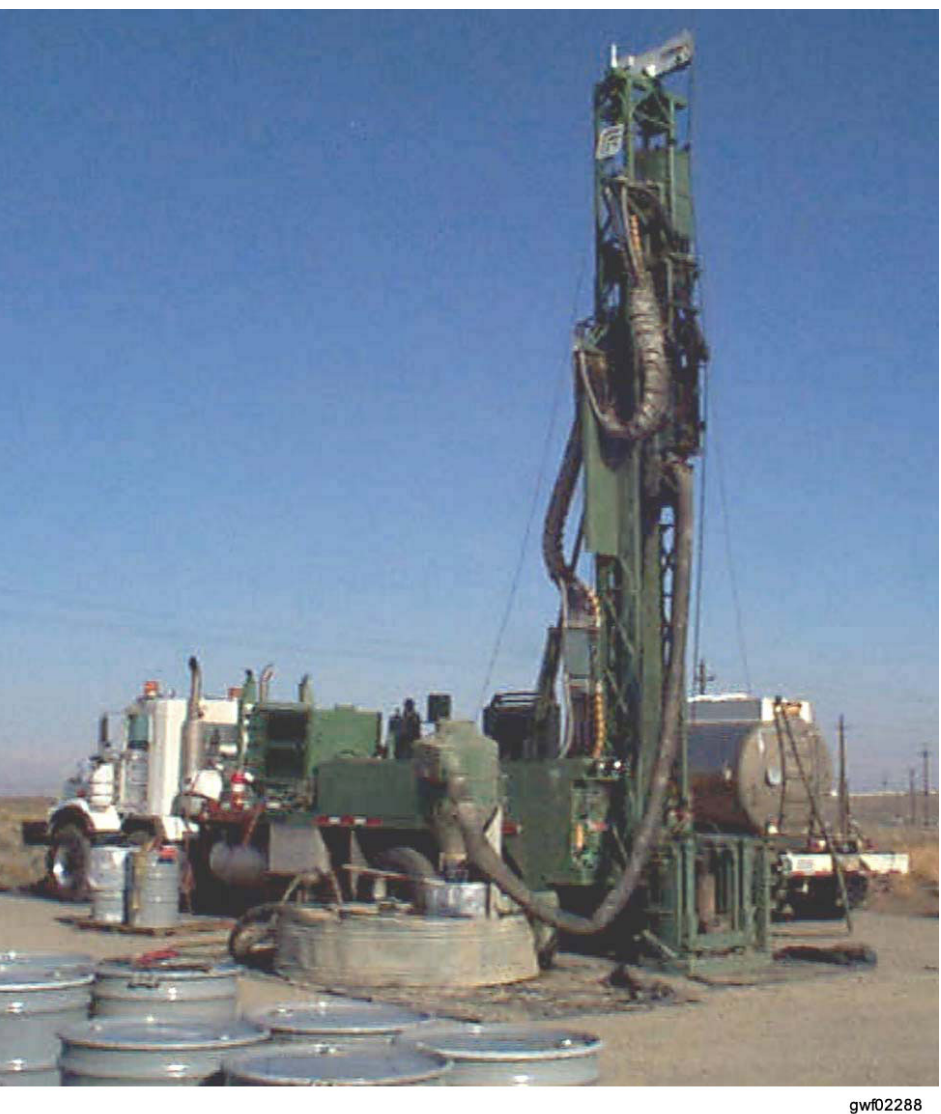

During fiscal year 2002, 28 new wells were installed on the Hanford Site.

- Liquid Effluent Retention Facility (200 East Area) - This site is monitored under an indicator evaluation program. However, it is monitored by just one useable downgradient well. Washington State Department of Ecology instructed DOE to cease statistical evaluations.

- Single-Shell Tank Waste Management Areas A-AX and C (200 East Area) - Indicator evaluation monitoring continued. Directions of groundwater flow were re-interpreted and monitoring networks are being modified.

- Single-Shell Tank Waste Management Area B-BX-BY (200 East Area) These tank farms may have contributed to groundwater contamination in the northern 200 East Area. However, the assessment monitoring has not clearly identified a source within the tank farms. This waste management area is located near other major sources of contamination (e.g., the BY Cribs and 216-B-8 crib) that produced the bulk of the contamination.

- Single-Shell Tank Waste Management Area S-SX (200 West Area) Groundwater studies indicate that sources within the tank farms have contaminated groundwater with chromium. Assessment monitoring continued in fiscal year 2002.

- Single-Shell Tank Waste Management Area T (200 West Area) - Results of assessment monitoring indicate that chromium is elevated in groundwater but appears to have a source outside the waste management area. Contaminant concentrations vary with depth.

- Single-Shell Tank Waste Management Area TX-TY (200 West Area) Assessment monitoring continued in fiscal year 2002. Chromium concentrations 
The results of vadose zone characterization studies improve understanding of the distribution and movement of contamination between the ground surface and the water table.
Computer models of groundwater help predict future groundwater conditions and the movement of contaminants in groundwater. This information is important in planning waste management and cleanup activities at the Hanford Site. are elevated and increasing. There are no known upgradient sources of chromium, implicating the tank farm as the source of chromium contamination.

- Single-Shell Tank Waste Management Area U (200 West Area) Assessment monitoring continued in fiscal year 2002. Chromium concentrations are elevated in the southeast corner of the waste management area and are decreasing.

\section{Well Installation}

During calendar year 2002, drillers completed 2 new RCRA monitoring wells, 21 wells for operable unit remediation and monitoring in 100-D Area, 4 wells to monitor a proposed low-activity waste site in the 200 East Area, and 2 wells for operable unit monitoring in the 200 West Area. Well maintenance was carried out at 456 wells during fiscal year 2002. These activities included well or pump repair, cleaning, and general maintenance.

\section{Modeling}

Computer simulations of groundwater flow and contaminant movement are used to predict future conditions and to assess the effects of remediation systems. Pacific Northwest National Laboratory has responsibility for a site-wide, consolidated groundwater flow and transport model.

In fiscal year 2002, development of the site-wide groundwater model focused on improvements to the base-case model and development of additional alternative conceptual models. The alternative models address uncertainty in the extent and distribution of major mud units in the unconfined aquifer and uncertainty in the distribution of hydraulic conductivity in the Hanford formation. These factors affect how groundwater flows through the aquifer.

Pacific Northwest National Laboratory applied the site-wide groundwater model to determine the flow path and travel time for potential contaminant releases at each of the tank farms to the Columbia River. These simulations predicted that the majority of contaminant plumes will move to the north through the gap between Gable Mountain and Gable Butte toward the Columbia River. These results differ from previous assessments using the prior model, which predicted that most of the contaminants would move to the east, and that the northern route through the gap would cease to exist because the water table would drop below the top of the basalt. Modelers continue to investigate this region of uncertainty.

As part of the Groundwater Protection Program, Pacific Northwest National Laboratory continued developing the System Assessment Capability as a tool to predict cumulative site-wide effects from all significant Hanford Site contaminants. This tool integrates several linked models, beginning with the waste inventory and simulates release and movement through the vadose zone, groundwater, and Columbia River. In fiscal year 2002, modelers completed an initial assessment of 10 contaminants released from 890 waste sites, simulating movement of the contaminants from 1944 through 3050.

\section{Vadose Zone}

Subsurface source characterization, vadose zone monitoring, soil-vapor monitoring, and sediment sampling were conducted in fiscal year 2002.

DOE contractors studied the vadose zone at several sites in the 200 Areas to support remediation, and at one site in the 100-F Area to assess the effectiveness 
of surface remediation. The studies involved geophysical monitoring and analysis of soil samples and soil gas:

- Sampling in a test pit in the 100-F Area showed that contaminant levels generally decrease with depth, as previously observed in other 100 Areas.

- Samples from a borehole drilled through the 216-T-26 crib in the 200 West Area showed the presence of contamination from the surface to a depth of 18 meters. The primary contaminants were cesium-137, europium-154, cobalt-60, carbon tetrachloride, and chloroform. Contaminant distribution was strongly affected by stratigraphy, with greater concentrations near the contact between different sedimentary units.

- To help characterize the distribution of carbon tetrachloride, researchers studied samples from a new groundwater monitoring well near the Plutonium Finishing Plant and from two deepened wells near the 216-Z-9 trench. Results indicated that the vadose zone is not likely to be a source of contamination in these locations.

- Sediment samples from boreholes at the 216-B-38 trench and 216-B-7A crib in the north 200 East Area indicate that cesium-137, plutonium, and uranium appear to be concentrated in a silty, sandy gravel unit of the Hanford formation.

- Workers excavated test pits in the 216-A-29 ditch and 216-B-63 trench in the 200 East Area in fiscal year 2002 to support future decisions about cleanup. The samples contained contaminants including cesium-137, strontium-90, and plutonium-239/240 at levels above Hanford Site background.

Workers drilled and sampled three boreholes in locations of known or suspected contamination in the TX Tank Farm. Sediment samples were collected and analyzed for chemical, radiological, and geochemical properties. Results will be available in fiscal year 2003. One of the boreholes was outfitted with vadose zone monitoring equipment as it was backfilled.

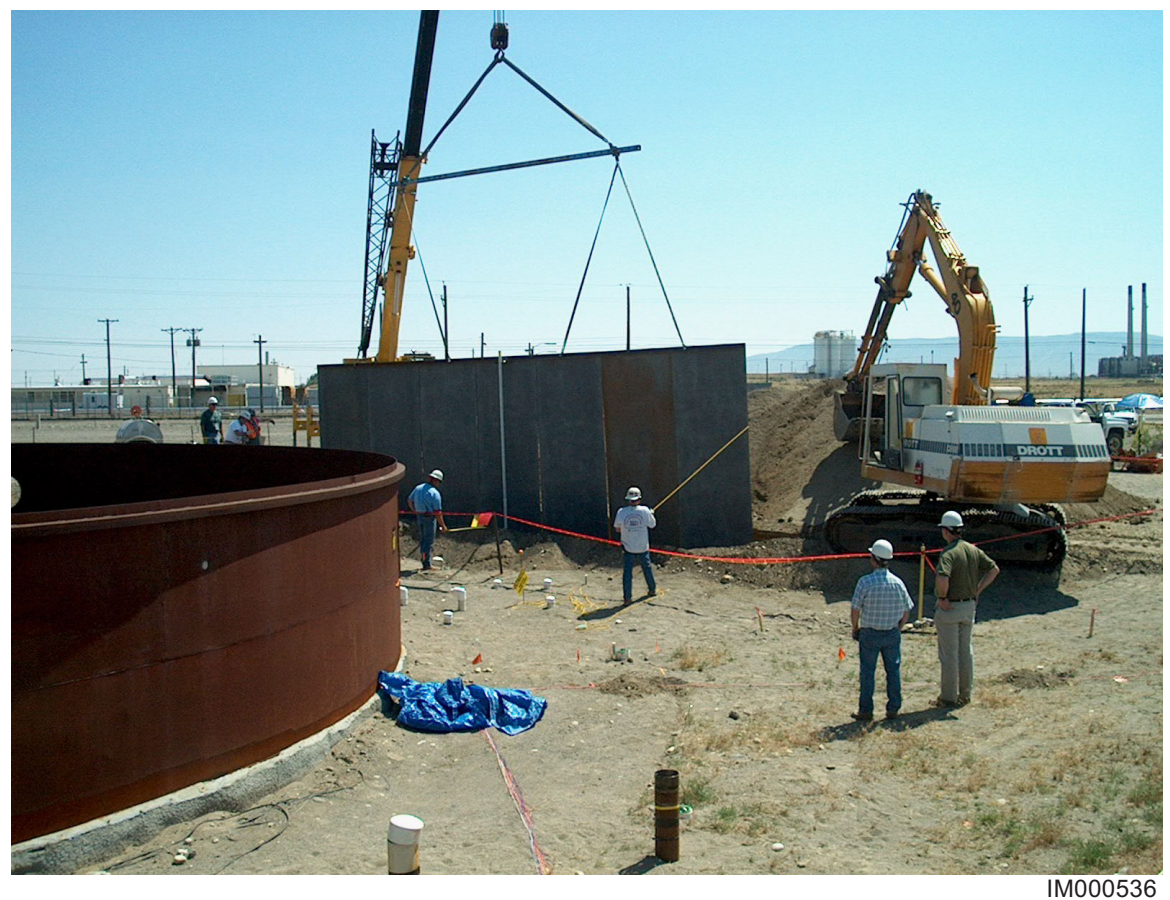

A steel sheet wall is installed at the mock tank study site to simulate an adjacent steel tank. Scientists studied technologies that could be used to detect leaks outside of a single-shell tank during waste retrieval operations.
Two electrical geophysical methods were tested at the 105-A Mock Tank Facility during 2002. These tests are helping scientists develop methods to detect leaks beneath buried waste tanks on the Hanford Site.
Air in the vadose zone can become contaminated with gaseous contaminants from landfills or other waste sites. At Hanford, soil gas is monitored in the 200 West Area to measure gaseous carbon tetrachloride and to assess how well vadose zone cleanup is working. 
At Waste Management Area B-BX-BY, results of geochemical characterization of core samples collected in fiscal year 2001 became available in 2002. Results suggest that strontium- 90 is fairly stable and immobile in the vadose zone. Uranium is present as a precipitate that currently is effectively immobile, but could dissolve from the sediment under certain chemical and physical conditions.

DOE monitors carbon tetrachloride in soil vapor near vadose zone remediation systems in the 200 West Area. Results indicate that the temporary suspension of vapor extraction during part of fiscal year 2002 caused minimal vertical transport of carbon tetrachloride through the soil to the atmosphere.

Researchers studied soil gas at the 618-10 burial ground (southeast Hanford Site) to determine whether there is a tritium plume similar to the one previously discovered at the 618-11 burial ground. Results indicated no significant tritium or volatile organic constituents from the 618-10 site. Results of the investigation also were used to guide locations for groundwater monitoring wells.

Geophysicists investigated the possibility of using gamma logging to identify zones of strontium-90 contamination in sediment around boreholes. Results showed a strong correlation between strontium-90 and gamma activity, and may lead to a method for quantitative measurement of strontium-90 in the subsurface.

Researchers evaluated performance parameters for two geophysical methods to detect leaks beneath buried tanks. Preliminary results from a test tank site indicate that the tested monitoring methods may be useful for detecting leaks from real tanks and estimating their volume.

In fiscal year 2002, DOE continued to take measures to protect tank farms from infiltration of water from precipitation or pipe leaks. Workers constructed berms and installed a culvert to carry water away from tank farms in the 200 East Area. DOE also tested water lines for leaks, and cut or capped unneeded water lines.

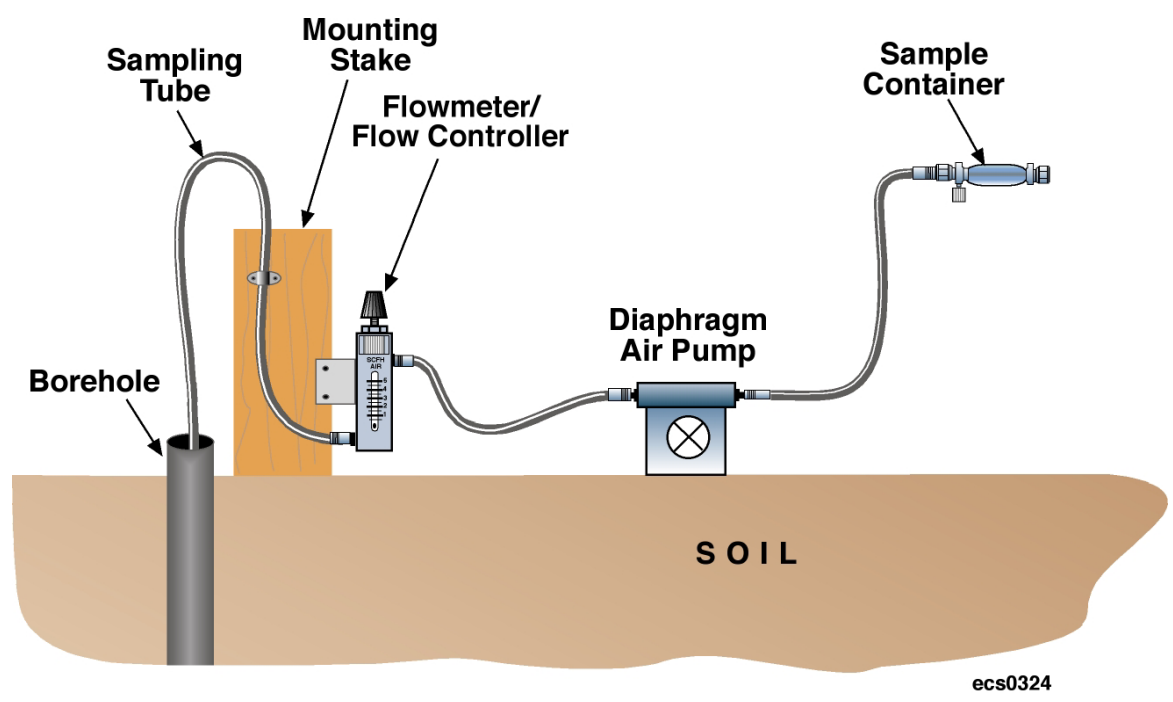

The above diagram shows a soil-gas sampling system. A probe is inserted into the soil through a borehole. Soil gas is drawn into the probe and pumped to the surface where it is collected and sent for laboratory analysis. Soil-gas sampling can be a powerful tool for locating and delineating contamination.

Scientists studied soil gas at the 618-10 burial ground to determine whether there is a tritium plume similar to the one previously discovered at the 618-11 burial ground. Results indicated no significant tritium from the 618-10 site. Results such as these can serve as a guide for locating new groundwater monitoring wells. 


\section{Glossary}

Aquifer - Underground sediment or rock that stores and/or transmits water, such as to wells and springs. Pores and cracks in an aquifer are saturated with water. The top of an unconfined aquifer is known as the water table.

Aquifer (confined) - An aquifer between layers of impermeable material such as dense rock or clay. Groundwater in a confined aquifer is under pressure so that when the aquifer is penetrated by a well, the water rises above the top of the aquifer. Aquifers within the Columbia River Basalt underlying the Hanford Site are confined aquifers.

Aquifer (unconfined) - An aquifer whose upper water surface (water table) is at atmospheric pressure. At Hanford, the unconfined aquifer is the uppermost aquifer and is most susceptible to contamination from site operations.

CERCLA - Comprehensive Environmental Response, Compensation, and Liability Act (42 USC 9601 et seq. as amended); federal law, enacted in 1980 and amended in 1986, that governs the cleanup of hazardous, toxic, and radioactive substances.

Crib - An underground chamber used to dispose of large volumes of low-level, radioactive liquid waste, usually constructed of loosely spaced timbers several feet below ground level; liquid would percolate through the chamber to the underlying soil; numerous cribs exist in the 100, 200, and 300 Areas.

Groundwater - Water that occurs below the Earth's surface. It is found within the pores of sand and gravel or the cracks of fractured rock beneath the land. Groundwater under the Hanford Site flows slowly toward the Columbia River. In this manner, groundwater may carry contamination from Hanford into the river.

Hanford Reach - Segment of the Columbia River that extends 85 kilometers (51 miles) downstream from Priest Rapids Dam to the head of the McNary Pool near the city of Richland, Washington.

Operable unit - Designation of a group of contaminant sources for characterization and cleanup under CERCLA. Groundwater operable units include the vadose zone and groundwater beneath the source operable units.

Permeability - Ability of sediment or rocks to allow the passage of a liquid, such as water. Permeable materials, such as gravel and sand, allow water to move quickly through them, whereas impermeable materials, such as clay or solid basalt, do not allow water to flow freely.

$\mathbf{p H}$ - Term used to indicate the acidity and alkalinity of a solution; $\mathrm{pH} 7$, the value for pure water, is regarded as neutral; $\mathrm{pH}$ values from 0 to 7 indicate acidity and $\mathrm{pH}$ values from 7 to 14 indicate alkalinity.

Plume - Volume of air, soil, or water containing contaminants. Groundwater plumes are usually depicted as two-dimensional maps.

Pore water - Water in the minute spaces of the substrate that forms the bottom of the Columbia River. 
RCRA - Resource Conservation and Recovery Act of 1976 (42 USC 6901 et seq. as amended, Public Law 94-580); federal law enacted in 1976 to address the treatment, storage, and disposal of hazardous waste.

Recharge - Water added to an aquifer. Natural recharge sources include rainfall that seeps into the ground. Artificial recharge originates from manmade sources such as irrigation or disposal of liquid waste to the ground.

Seeps - Areas on the river bank where water flows out of the aquifer into the river; also known as springs.

Specific conductance - A measure of the ability of water to conduct an electrical current; specific conductance is used in groundwater monitoring as an indication of the presence of ions of chemical substances that may have been released by a leaking waste storage or disposal facility.

Surface water - Water that is on the Earth's surface, such as in a stream, river, lake, or reservoir.

Tri-Party Agreement - Federal Facility Compliance Agreement signed in 1989 by the U.S. Department of Energy, the state of Washington, and the U.S. Environmental Protection Agency. The agreement includes schedules and milestones for completion of Hanford Site cleanup.

Trench - A narrow ditch dug in the soil used to dispose of solid and liquid waste from Hanford operations.

Vadose zone - Area between the surface of the ground and the water table, where pores between sediment grains hold a mixture of air and water.

Waste management area - A grouping of waste sources regulated as one unit under RCRA (e.g., a group of underground storage tanks and associated pipelines).

Water table - Top of an unconfined aquifer; top of the saturated sediment or rock. 